تاريخ الإرسال (2021-1-21)، تاريخ قبول النشر (28-31-28)

\begin{tabular}{|c|c|c|}
\hline . & د. نادر أحمد العتوم & اسم الباحث الأول: \\
\hline 2 & د. محمد مصلح عبابنة & اسم الباحث الثاني : \\
\hline & وزارة الأوقاف، إربد، الأ & 1 اسم الجامعة والبلد (للأول) \\
\hline & وزارة التربية والتعليم، إ & 2 اسم الجامعة والبلد (للثانيي) \\
\hline
\end{tabular}

* البريد الالكتروني للباحث المرسل:

E-mail address:

nalottuom@gmail.com

\section{القيم المتعلقة بالمساجد الواردة في السنة النبوية وتطبيقاتها التربوية}

https://doi.org/10.33976/IUGJIS.30.1/2022/12

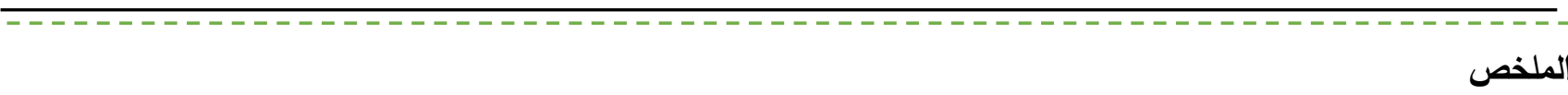

تهدف الدراسة إلى بيان المفهوم العام للقيم، والكثف عن طبيعة القيم المتعلقة بالمساجد الواردة في السنة النبوية، وبيان التطبيقات

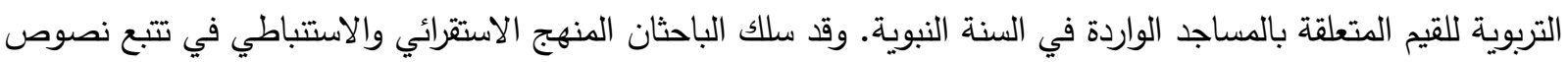
الأحاديث الصحيحة، ثم تحليلها واستتتاج ما تضمنته من القيم المسجدية. وتوصل الباحثان إلى عدة نتائج أهمها: أن للقيم أشكالاً

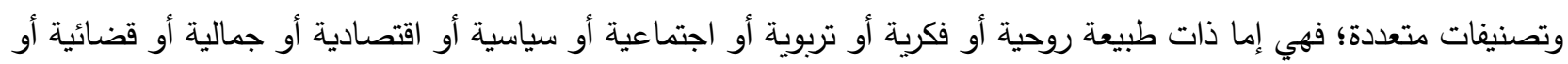

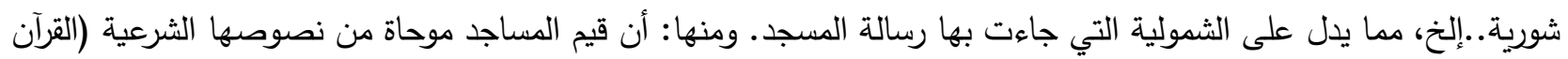
والسنة)، وهي تتفاضل فيما بينها، وعلاقتها بالمساجد علاقة تشارك وتلازم، تشكل فيما بينها منظومة بنائية متكاملة لا ينفك إحداها

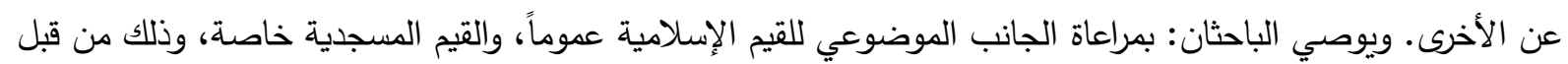

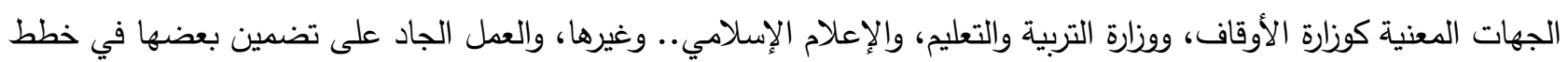
المناهج المدرسية، والمساقات الجامعية، بهدف تقوية الجانب الإيماني من خلال تعزيز القيم المسجدية عند أبناء المسلمين. (الكلمات المفتاحية: (القيم، المساجد، السنة النبوية، التطبيقات).

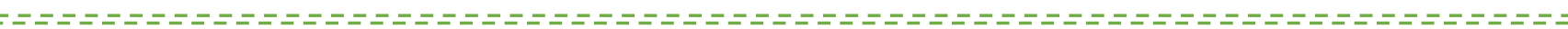

Masjed Related Values Mentioned in Prophet Sunna and their Educational Applications

This study sought to identify the general concept of values; to reveal the nature of Masjed related values mentioned in Prophet Sunna and to identify their educational applications. The study adopted the descriptive and deductive design in tracing correct Hadeath texts then analyzing them and finally deducting what they included of Masjed values. The study concluded with several results, the most significant is that values take various forms and classifications; they are spiritual, intellectual, educational, social, political, economic, aesthetic, judicial or democratic; and this implies that Al-Masjed message is integrated. The results also found that Masjed values are taken from Shari texts and they differ between them and that its relationship to Masjed is collaborative which implies that they form and integrated structural system that cannot be detached. The study recommends to consider the thematic aspects of Islamic values in general and Masjed values in particular by the related authorities such as Al-Awqaf Ministry and Ministry of Education and other departments. There is a need to make an effort to include some of these values in curricula plans and course syllabi to strengthen the spiritual aspect by promoting Masjed values among Muslim children.
\end{abstract}

Keywords: (Values, Masjed, Prophet Sunna, Applications). 


\section{المقدمة}

الحمد الله ربّ العالمين، والصلاة والسلام على سيّّ المرسلين محمد، وعلى آله وصحبه أجمعين، وبعد.

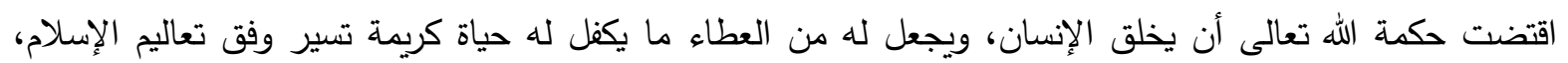

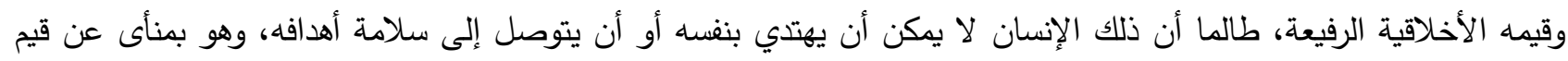

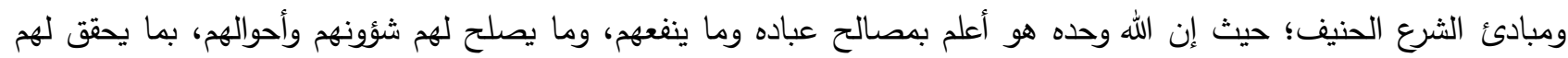

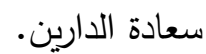
والمتأمل في النصوص الشرعية من كتاب الله وسنة نبيه المطهرة، يجد أنها اشتملت على منظومة متكاملة من القيم التربوية والتعليمية، ترمي إلى تزكية الفرد المسلم، والارتقاء به إلى أعلى مراتب الكمال الإنساني، تحقيقاً لمنهج الخلافة وعمارة

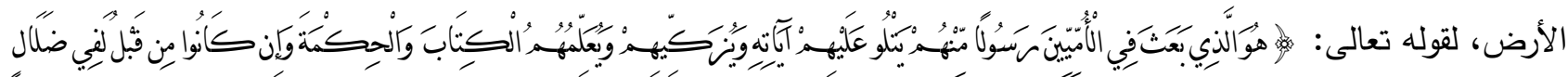

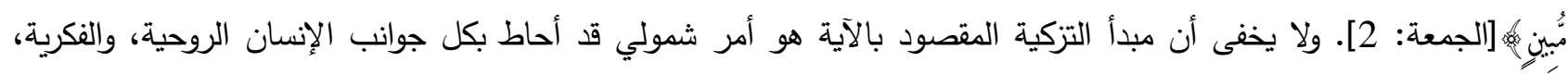
والسياسية، والاجتماعية، والاقتصادية، والحضارية وغيرها..، لتحرير البشر من قيود العبودية لغير الله تعالى، وتطهيرهم من لوثات الهوى، وحب الدنيا، والركون إليها. ونظراً لما تعيشه الأمة الإسلامية - في وقتنا الراهن - من تحديات معاصرة أخذت تفت في عضد أبناء المسلمين، من نزاعات، وصراعات إقليمية، وانقسامات مذهبية وطائفية، والسعي وراء المصالح الدنيوية الهابطة..، فضلاً عن التبعية الفكرية،

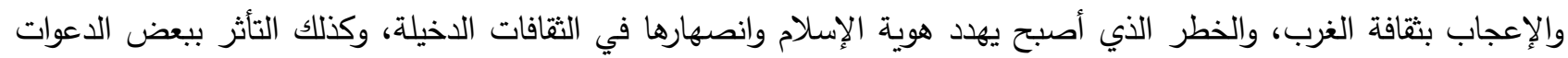

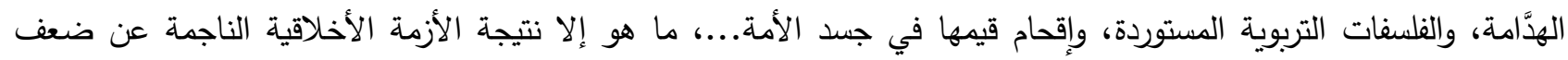

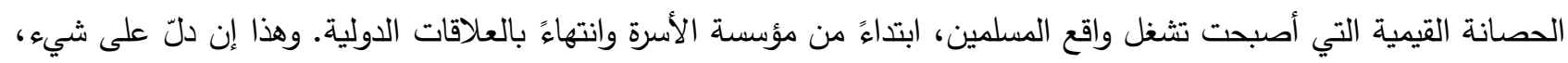
فإنما يدل على هجر القيم الإسلامية من قبل أبنائها التي كفلت لهم بناء حضارة إسلامية سامقة، تثكل حصناً منيعاً أمام كيد

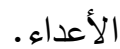

لذا، فإن مسألة الرجوع إلى القيم الإسلامية المستمدة من مصادرها الثرعية (الكتاب والسنة)، وتطبيقها على أرض واقع

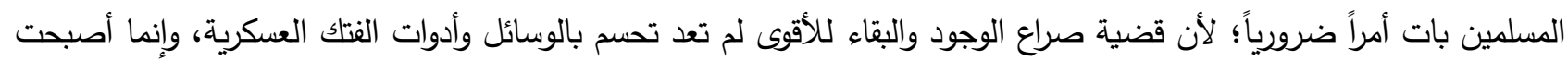
تدار من قبل أجندات، ومخططات أيديولوجية مغرضة تهدف إلى غزو أخلاق الثباب المسلم، وعزلهم عن مصفوفة القدية القيم الإسلامية التي تربطهم بدينهم، وعلى رأسها قيم التوحيد والعبادة التي انبثق شعاعها من مؤسسة المساجد، وتخرج من محاريبها جيل حضاري توني مؤمن باله، يقدم على التضحية كما يقدم أهل الثرك على بلى الحياة. ولما كانت المساجد تعد من أهم الوسائط التزبوية التي تُعنى في تتشئة، وإعداد جيل مسلم قادر على الدئل الدفاع عن هويته

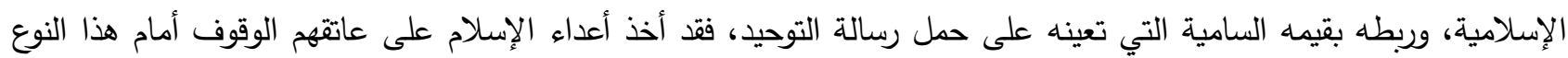

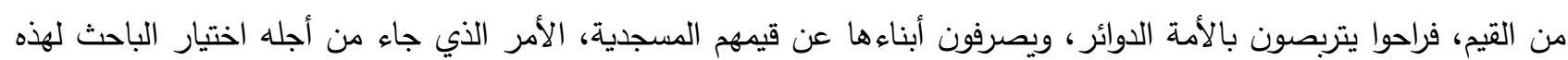

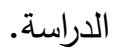

\section{مشكلة البحث وأسئلته}

تأتي مشكلة البحث بناءً على خلفية الدوافع أو المنطلقات التي دعت الباحث إلى الوقوف على حقيقتها، أهمها: غربة

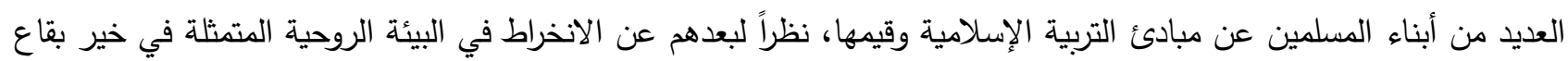

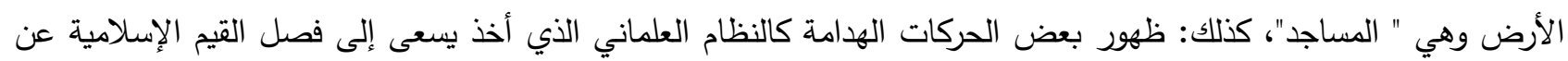

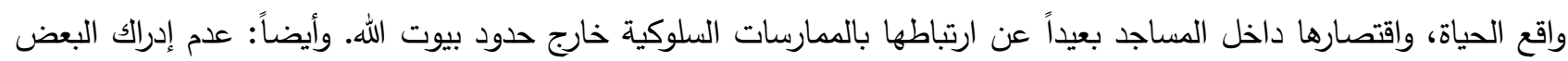




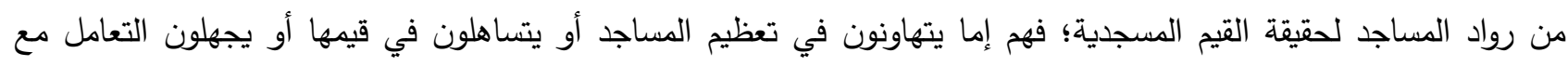
الأحكام والثعائر المتعلقة بها، إضافة إلى شح البحوث التي لم تطرق هذا النوع من الدراسة في هذا الحقل التربوي. على ضوء ما سبق، يكون السؤال الرئيس للبحث:

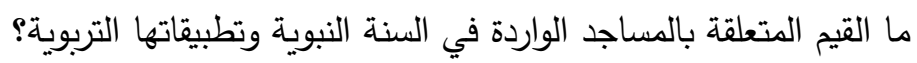

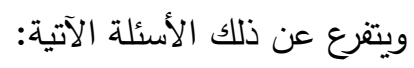

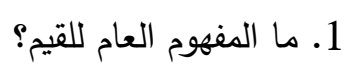

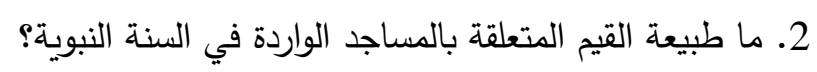

3. ما التطبيقات التربوية للقيم المتعلقة بالمساجد الواردة في السنة النبوية؟ بالئج

أهداف البحث

تسعى الدراسة إلى الإجابة عن الهدف المحوري الرئيس من خلال تحقيق الآتي:

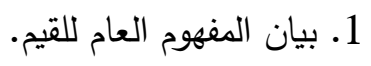

2. الكثف عن طبيعة القيم المتعلقة بالمساجد الواردة في السنة النبوية.

3. بيان التطبيقات التربوية للقيم المتعلقة بالمساجد الواردة في السنة النبوية.

حدود البحث

تقتصر حدود البحث على استعراض القيم المتعلقة بالمساجد الواردة ذكرها في النصوص الحديثية الصحيحة المقصورة

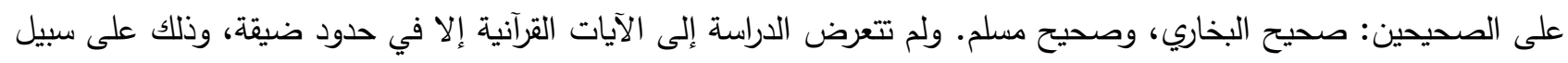
الاستشهاد أو الاستئناس.

منهج البحث

يسلك الباحث في هذه الدراسة ما يأتي:

1. المنهج الاستقرائي: من خلال استقراء نصوص الأهاء لأحاديث الصحيحة البالغ عددها (51) حديثاً والتي تتاولت القيم المتعلقة بالمساجد، وذلك كما جاءت في الصحيحين. 2. المنهج الاستتباطي: وذلك باستنباط وتحليل منظومة القيم المتعلقة بالمساجد، وذلك بعد القراءة الفاحصة لشروحات

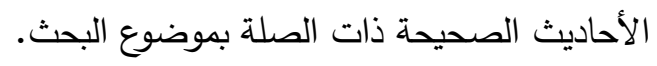

خطة البحث

تثنتمل خطة البحث على ثلاثة مباحث، هي كالآتي: المبحث الأول: المفهوم العام للقيم.

المبحث الثاني: طبيعة القيم المتعلقة بالمساجد الواردة في السنة النبوية. المبحث الثالث: التطبيقات التربوية للقيم المتعلقة بالمساجد الواردة في السنة النبوية.

الارراسات السابقة

توصل الباحثان إلى عدة دراسات سابقة ذات صلة قريبة لموضوع الدراسة، هي كالآتي:

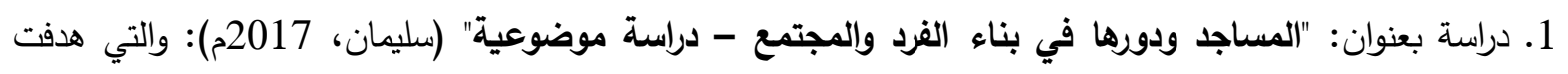

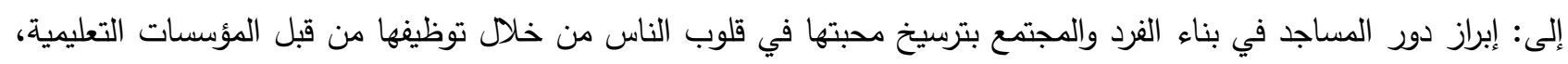
والتربوية، والاجتماعية، وكذلك إبراز وظائفها المتتوعة في جميع مجالات الحياة المختلفة. واتبعت الباحثة المنهج الاستقرائي 
والمنهج الوصفي. وتوصلت الدراسة إلى عدة استتاجات أهمها: المسجد يعد مركزاً تعليمياً له أدوار متعددة تمتاز بالثمولية والتكامل في أمور الدنيا والآخرة، وكذلك قدرته على إعداد الجند والقادة.

2. دراسة بعنوان: "دور المسجد الدعوي والتربوي - مسجد بحري الكبير نموذجاً" (أحمد، 2016م): والتي هدفت إلى:

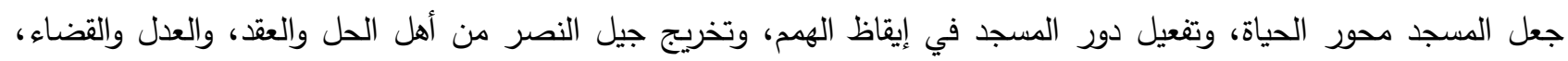

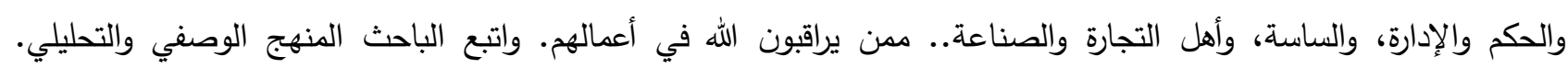

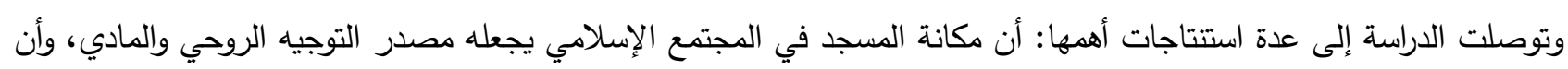
النهوض الحضاري للأمة والتخلص من عوامل التخلف والضعف لا يمكن أن يتحقق إلا إذا جعل المسجد محوراً للحياة. 3. دراسة بعنوان: "الدور التربوي للمسجد النبوي الثريف" (الجهني، 1419هـ): والتي هدفت إلى إنى التعرف على على أهمية

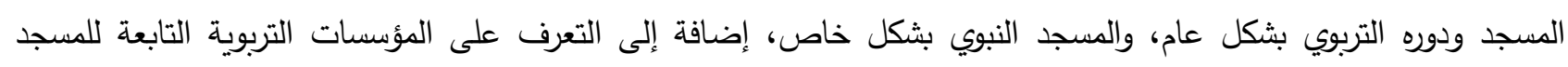

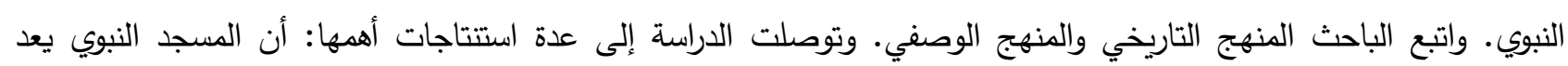

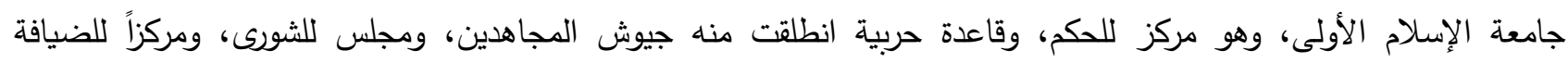
واستقبال الوفود، وكذلك النشاط الثقافي والتعليمي الواسع الذي يقوم به المسجد النبوي في شتى أنواع المعرفة.

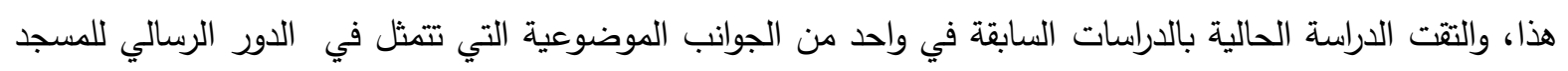
في بعض المجالات الحياتية. بينما افترقت الدراسة الحالية عن الدراسات السابقة في تتاولها للقيم الإسلامية المرتبطة برسالة

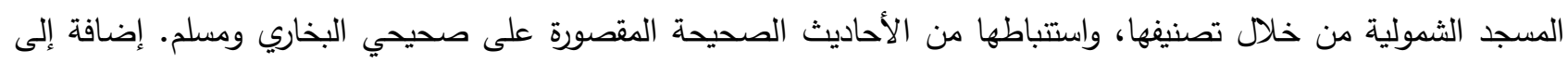

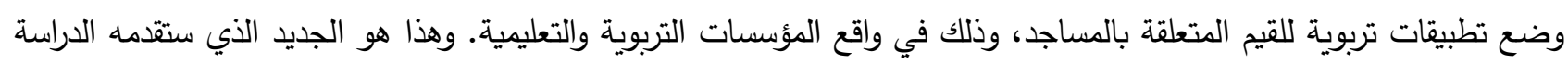
إن شاء الله تعالى.

\section{المبحث الأول \\ المفهوم العام للقيم}

المطلب الأول: تعريف القيم في اللغة

جاء في معجم مقاييس اللغة:(1) القاف والواو والميم أصلان صحيحان، يدل أحدهما على جماعة ناس، وربما استعير في

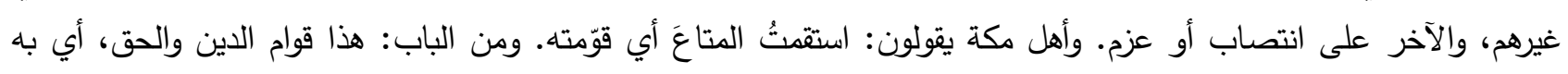
يقوم.

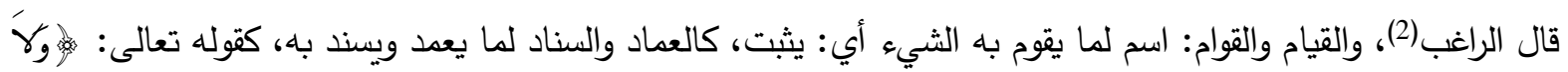

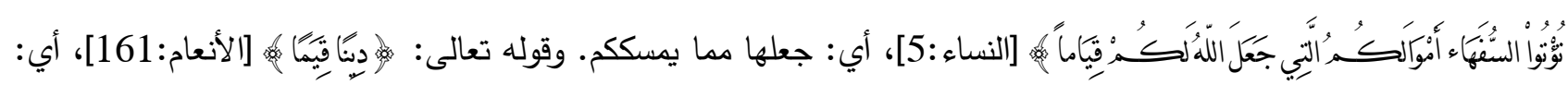

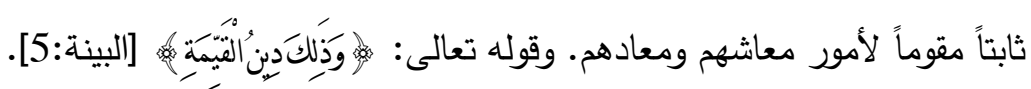

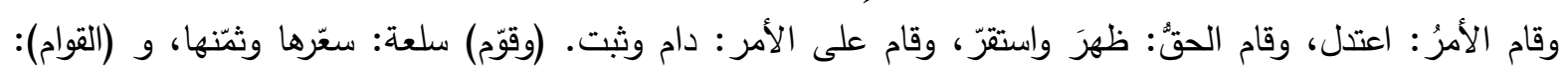

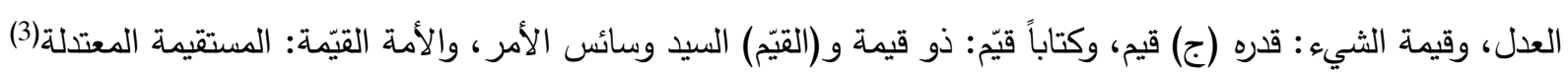

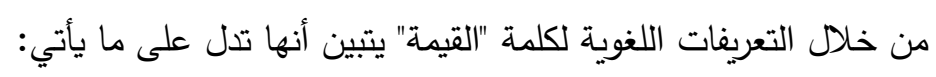
1. 1 - n العزم والاختيار.

$$
\begin{aligned}
& \text { (1) ابن فارس، معجم مقاييس اللغة (ص48). باب (قوم). }
\end{aligned}
$$

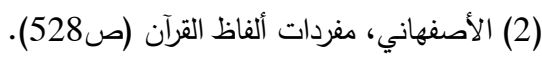

$$
\begin{aligned}
& \text { (3) مصطفى وآخرون، المعجم الوسيط (ج2/ العزان (267). }
\end{aligned}
$$


2. مراعاة المصالح وحفظها.

3. الاعتدال والتوسط والاستقامة.

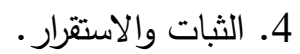

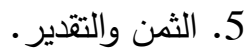

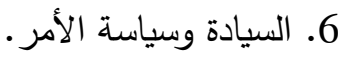

وهذه المعاني لا تبتعد كثيراً في دلالتها اللغوية عن المعاني الاصطلاحية العامة كما قررها علماء التربية، وعلماء النفس

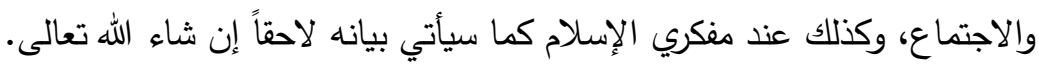

المطلب الثاني: تعريف القيم في الاصطلاح

لقد شاع مصطلح "القيمة" والذي يعني أصلاً ما يستحقه الثيء أو يساويه بحسب فائدته، ومنفعته، وندرته، والجها

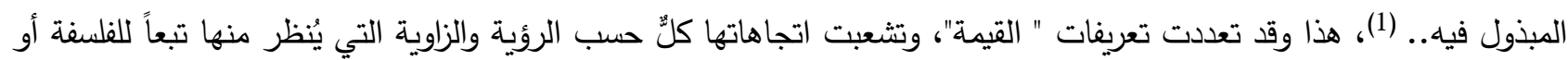

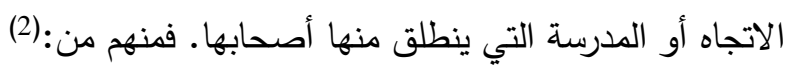
- نظر إلى القيم باعتبارها مجموعة من المعايير التي يحكم بها على منه الأشياء بالحسن والتهبح.

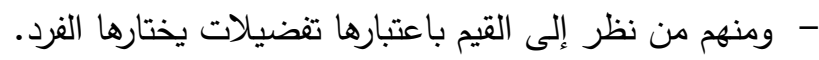

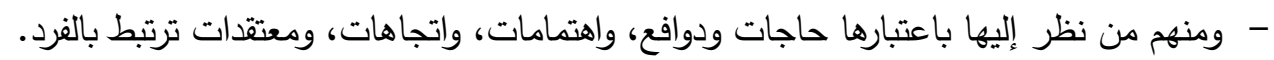

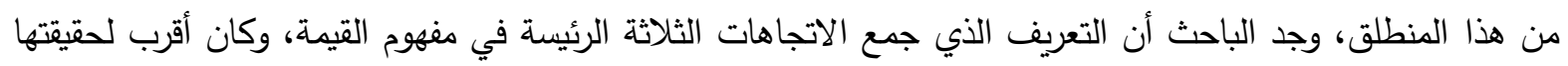
ما ذهب إليه أبو العينين(3)، بأن القيم: "مجموعة من المعايير والأحكام، تتكون لدى الفرد من خلال تفاعله مع المواقف والخبرات الفردية والاجتماعية؛ بحيث تمكنه من اختيار أهداف وتوجهات لحياته، يراها جديرة بتوظيف إمكانياته، وتتجسد خلال الاهتمامات

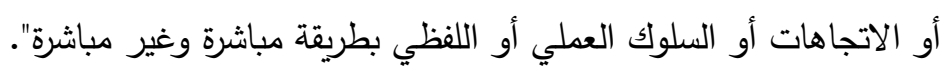
ويمكن تصنيف التعريفات المتعلقة بمفهوم "القيمة" عند بعض العلماء والمفكرين المسلمين في علوم التربية وعلم

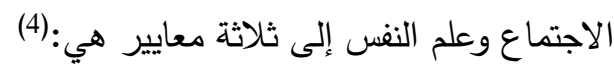

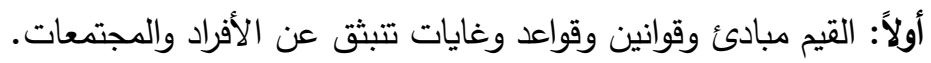

ثانياً: القيم انعكاسات لسلوك الأفراد.

ثالثاً: القيم معيار لتقويم سلوك الفرد.

مما سبق، يعرف الباحث "القيم" بأنها: تلك المفاهيم والمعايير المكتسبة التي تحمل في ذاتها قوة اعتبارية تهدف إلى تتظيم

علاقات أفراد المجتمع، وتوجيه سلوكاتهم نحو تحقيق مرادهم منها بالأخذ أو الترك.

المطلب الثالث: مفهوم القيم في الإسلام وعلاقتها بالأخلاق مراق

إن مصطلح "القيمة" باعتباره من المفاهيم التربوية المعاصرة لم يكن مستخدماً عند علماء ومفكري الإسلام الأوائل، وإنما هو من الألفاظ التي دخلت حديثاً نطاق الفكر التربوي المعاصر ؛ وذلك بعد أن بدأ الاهتمام بدراسة القيم في مجالات الدراسات النفسية والاجتماعية في الثلاثينيات والأربعينيات من القرن الماضي من قبل بعض على علماء الغرب(5).

(1) الأسمر ، فلسفة التربية في الإسلام (ص479).

(2) الجلاد، تعلم القيم وتعليمها (ص21).

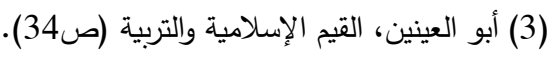

(4) المهيدات، نظرية القيم التعليمية في الفكر الإسلامي وتطبيقاتها التربوية (ص28) الإنية.

(5) خليفة، إرتقاء القيم (ص14).

372 IUG Journal of Islamic Studies (Islamic University of Gaza) / CC BY 4.0 
وقد عبر عن "القيمة" في الإسلام بأساليب، وقواعد أخلاقية، وآداب سلوكية تخاطب الإنسان وتربطه بواقعه، وبالتالي ليس

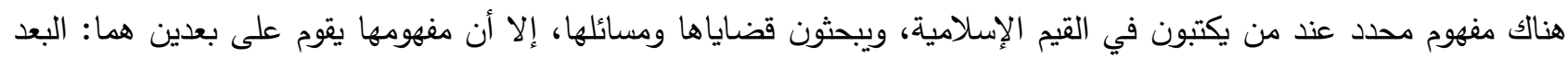
السلوكي، والحكم الشرعي الذي يحكم به على هذا السلوك من حيث كونه حسناً أو قبيحاً (1).

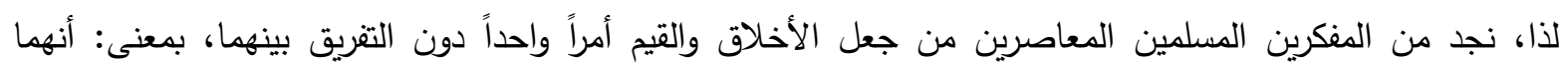

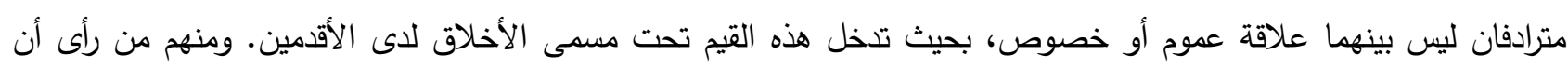

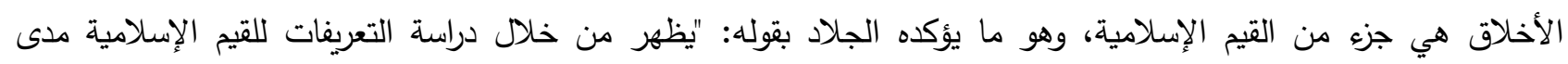
الاختلاف بين الباحثين في تحديد إطارها ما بين مضيق لها لتعني "الأخلاق الإسلامية"، وما بين موسع يجعلها مرادفة ومساوية لمفهوم الإسلام ذاته"(2). ومهما يكن، فإذا ما أردنا حسم الإشكال الإصطلاحي المتعلق بالأخلاق والقيم الإسلامية، فإن الباحث يرى: أنه لا مشاحة

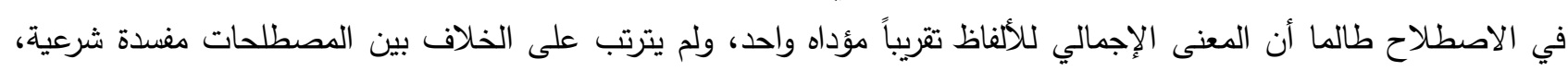
كما هو مقرر عند الأصوليين. ويمكن القول: إن كل معنى ينطوي على أهمية اعتبارية في نصوص الثرع، يحمل في ذاته قيمة أصيلة، فهو يعد من

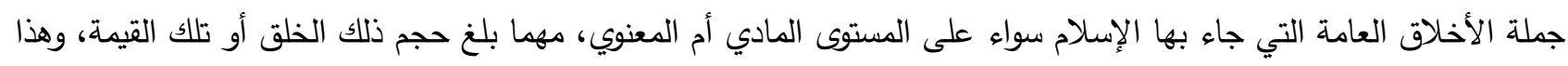

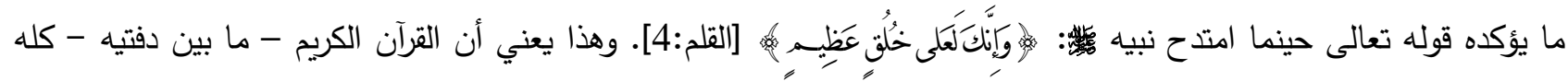
أخلاق في أحكامه، وتشريعاته، ومبادئه، وآدابه، وقصصد،، وأمثاله، وعبره.. في الوقت الذي يعذّها علماء التربية ومفكرو الإسلام قيماً إسلامية.

والذي يترجح لدى الباحث: هو أن مصطلحي (القيم والأخلاق) تربطهما علاقة تثاركية من جهة الجانب المعنوي سلباً

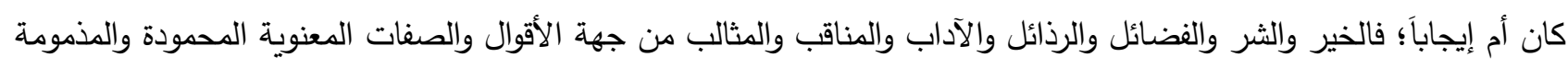

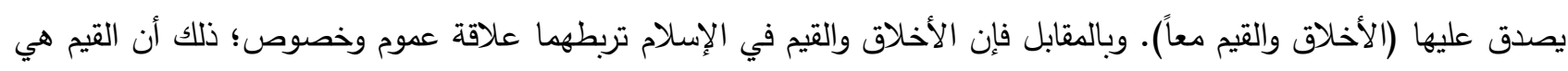

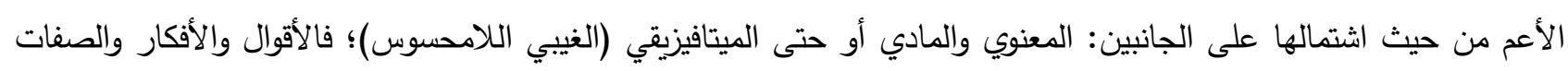

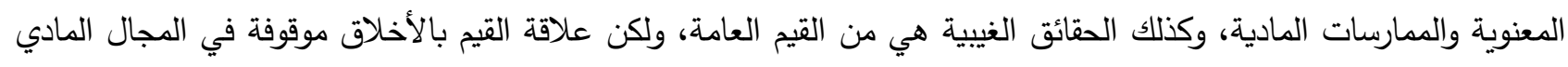

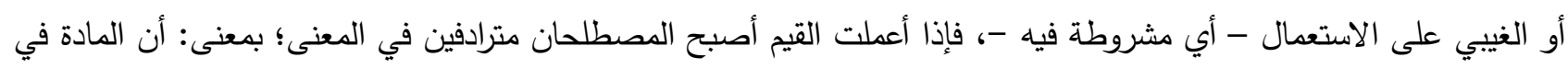

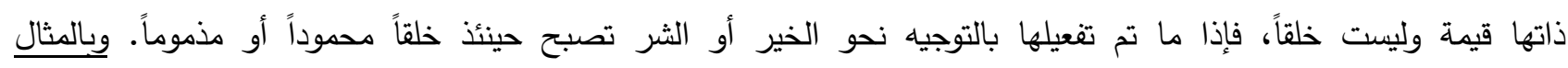

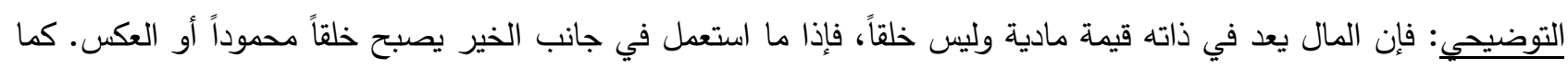

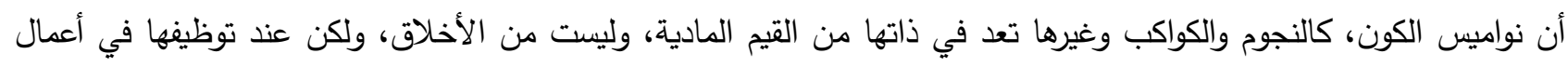

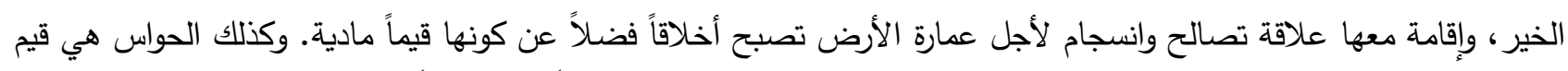

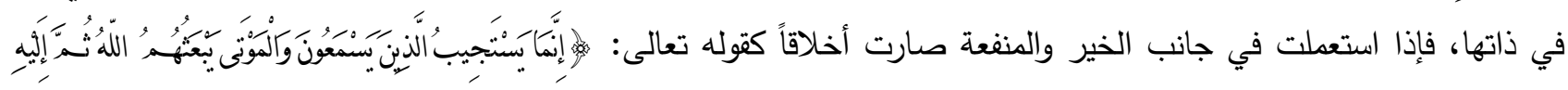

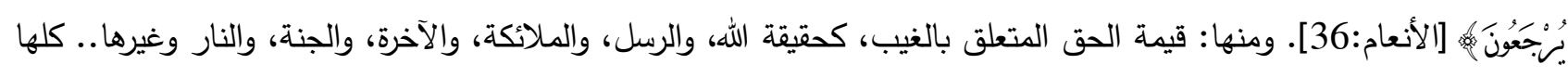
تعد من القيم الغيبية، فإذا ما استثرت هذه القيم لصالح الإيمان، والتقرب من الله تعالى بالعبادة والطاعة، تصبح تلك القيم أخلاقاً محمودة أو مذمومة إذا كان الأمر خلاف ذلك. وبالتالي تكون القيم والأخلاق بالنسبة لتلك المعادلة شيئين مترادفين. 
والمتأمل في القيم الإسلامية يجد أنها تختلف عن غيرها من القيم الوضعية، وذلك كونها مستقاة من قبل الوحي الذي جاء من أجل الارتقاء بالمسلم فيما يتعلق ببناء شخصيته، وضبط وتوجيه سلوكاته، وميولاته، واتجاهاته في كل جوانب الحياة، من خلال امتثال أوامر الإسلام، واجتتاب نواهيه، والتحلي بقيمه الأخلاقية، وتحقيق كل الأسباب التي تكفل له سعادة الدارين. لذا، فقد عرفت القيسي(1) القيم الإسلامية بأنها: "مجموعة من المثل العليا، والغايات، والمعتقدات، والتشريعات، والوسائل، والضوابط، والمعايير لسلوك الفرد والجماعة، مصدرها الله عز وجل. وهذه القيم هي التي تحدد علاقة الإنسان وتوجهه إجمالاً وتفصيلاً مع الله تعالى، ومع نفسه، ومع الكون، وتتضمن هذه القيم غايات ووسائل". وقد تعرّف القيم الإسلامية بأنها: "حكم يصدره الإنسان على شيء ما مهتدئ وندياً بمجموعة المبادئ والمعايير التي ارتضاها الشرع محدداً المرغوب فيه والمرغوب عنه من السلوك"(2). ولعل التعريف الأول هو الدختار لاى الباحث، كونه الأقرب بالنسبة لهذه الدراسة، ولما فيه من إحاطة وشمولية لعناصر ومعطيات القيم من منظور الإسلام.

وبناء على التعريفات السابقة، يتوصل الباحث إلى أن القيم في الإسلام تتصف بمزايا عدة أهمها: 1. إن مصدرية القيم في الإسلام هي الكتاب الكريم والسنة المطهرة. 2. إن القيم في الإسلام مرتبطة بالمبادئ والمعايير والضوابط التي تحكم السلوك الإنساني على مستوى الفرد والجماعة؛ فهي تجمع بين القول والعمل والفكر والسلوك. 3. شمولية القيم الإسلامية لكافة جوانب الحياة المعنوية منها والمادية.

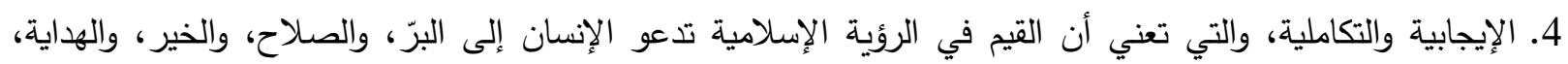

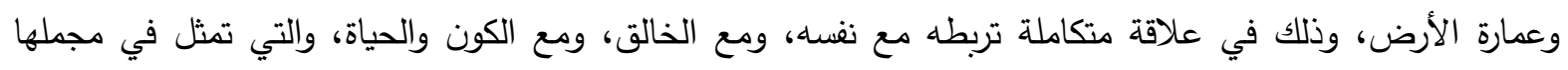

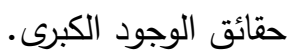
5. إن القيم السلبية (المرغوب عنها) في الإسلام تصل إلى مرتبة أقوى من القيم الإيجابية (المرغوب فيها)؛ لإنها تمثل جملة

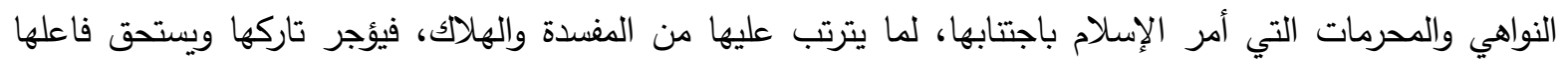

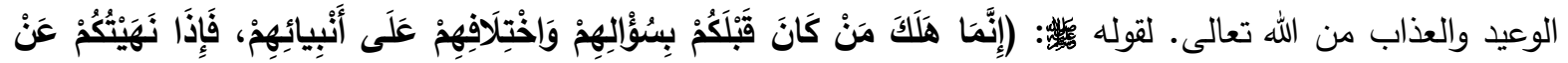

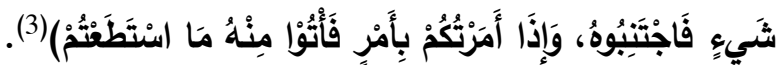
6. إن القيم في الإسلام تمتاز بالثبات والاستقرار، لثبوت مصدريتها وهو الكتاب والسنة، وهي غير قابلة للتغيير على مر مرانير العصور والأمكنة، وإنما التغيير الذي يطرأ في بعض فروعها هو من باب المرونة، وذلك لما تتتضيه المصلحة الثرعية التي جاء الإسلام للمحافظة عليها (4). 


\section{المبحث الثاني \\ طبيعة القيم المتعلقة بالمساجد الواردة في السنة النبوية}

يتتاول هذا المبحث طبيعة القيم المتعلقة بالمساجد، والتي تتضمن حقيقة القيم المسجدية من حيث نوعها وأثكالها أو المجالات والأبعاد التي تتدرج تحتها تلك القيم، وهذا يتطلب الحديث أولاً عن مفهوم المسجد، وأهمية تعلم القيم المتعلقة بالمساجد،

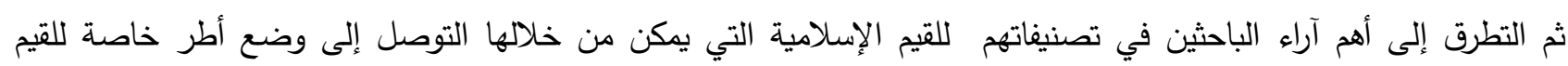

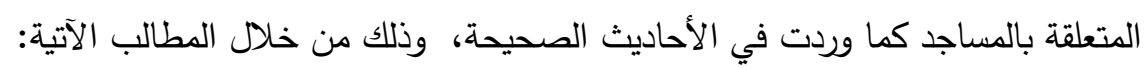

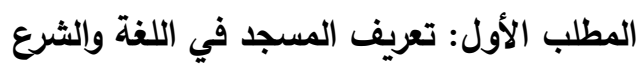

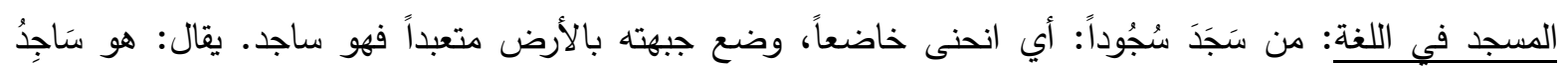

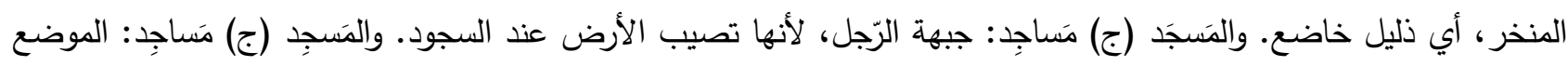

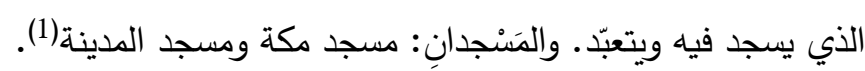
وأما شرعاً: فهو الموضع الذي يسجد والئدئ فيه، وكل موضع يتعبد فيه الإنسان فهو مسجد، وعليه، فإن الأرض كلها مسجد إلا

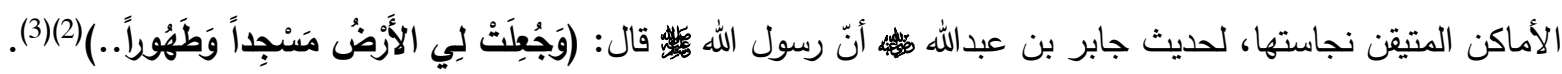

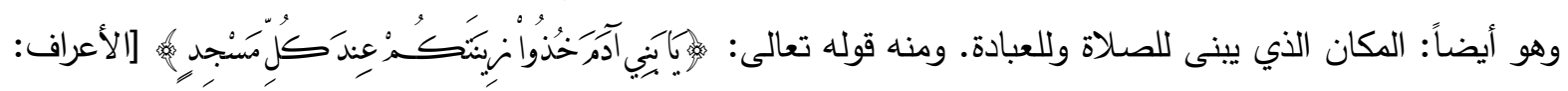

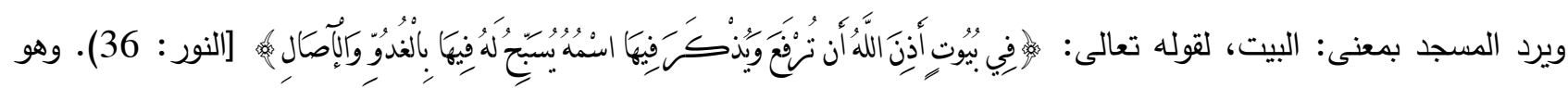
المعنى المراد بحثه في موضوع القيم. المطلب الثاني: أهمية تعلم القيم المتعلقة بالمساجد تظهر أهمية دراسة القيم المتعلقة بالمساجد والحاجة إلى تعلمها، وذلك من خلال عدة أسباب يقسمها الباحث إلى ما يأتي: أولاً: عوامل غير مباشرة، وتتمثل في: 1. الضياع والتخبط الواضحين في اختيار المبادئ والقيم التي تتبناها الدول والمجتمعات الإسلامية، نتيجة للهموم التي تعيشها تلك الدول وشعوبها من التخلف، والاتحطاط، والظلم الاجتماعي وغيرها.. 2. التحدي الثقافي والحضاري الذي تواجهه الدول الإسلامية وشعوبها اليوم(5).

3. إنها ضرورية لتغلب الأمة الإسلامية على أسباب التخلف، ومحاربة القيم الدخيلة التي لا تتسجم مع القيم الإسلامية.

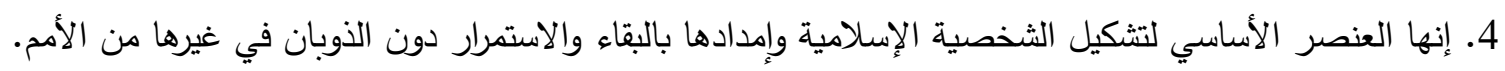

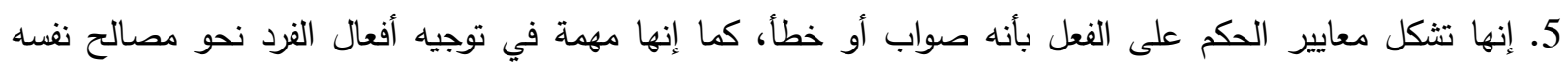
ومصالح الجماعة التي يعيش فيها. 6. إنها ضرورية لتماسك النظام الاجتماعي، والحفاظ على وحدة صف الأمة الإسلامية(6). 


\section{ثانياً: عوامل مباشرة، ويرى الباحث أنها تتمثل في:}

1. المحافظة على هيبة المسجد وقدسيته ومكانته الدينية منعاً للعبث والفساد المادي أو المعنوي، وقطع كل أسباب النزاع

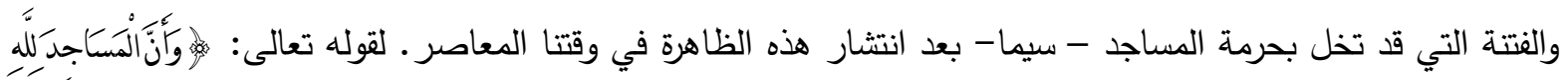

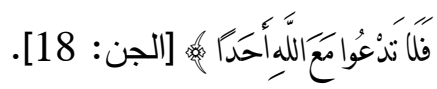
2. تقوية وتعزيز الجانب الإيماني والتعبدي الذي من شأنه أن يسهم في تقويم وضبط شخصية الفرد المسلم فكراً، وسلوكاً،

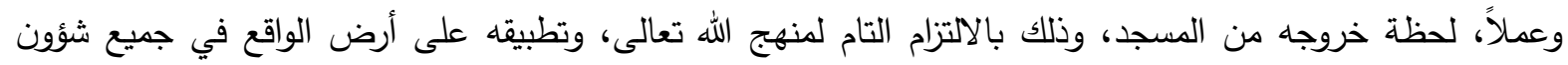

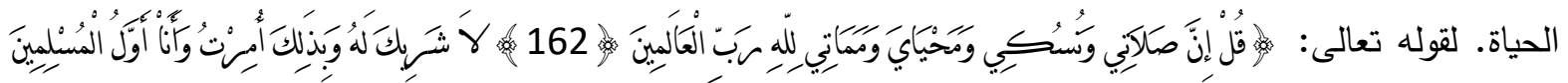

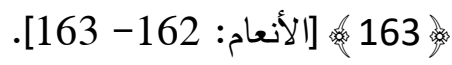

3. تحقيق المعنى الثمولي لرسالة المسجد ونقله من دائرة المفهوم الضيق للعبادة كالصلاة والذكر وقراءة القرآن.. إلى المفهوم الأوسع، ليصبح المسجد جامعة تقوم على أكتافه ميادين الحياة كما كان في العهد النبوي والراشدي؛ فهو:(1) "مجلس للثعب، وبيت للمال، ومستثفى للمصابين، ودار للقضاء، ونادٍ للرياضة والترفيه، ومكان للفرح وآخر للترح. كما كان

المسجد مقراً للتعليم، ولاستقبال الوفود، والاحتفالات وغير ذلك مما يدل على أهميته في حياة المسلمين"(2. .

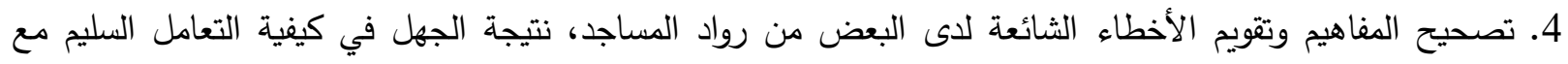
المواقف، وعدم معرفة بعض الأحكام الفقهية المتعلقة بالمسجد، مثل: كيفية الصلاة على الكرسي، والتكلم أثناء خطبة لتصنية

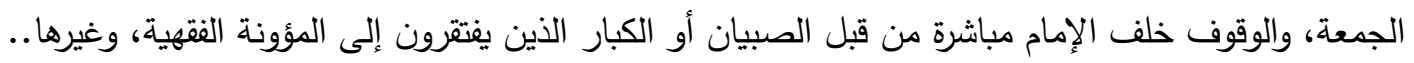

\section{المطلب الثالث: تصنيفات القيم الإسلامية وعلاقتها بالمساجد}

يعرض الباحث في هذا الموضع أهم تصنيفات القيم الإسلامية من غير تفصيل - لا سيما- أن علماء التربية المسلمين قد أجادوا في ذكر أثكال القيم وتصنيفاتها، وهذا يفيد الوصول من خلالها إلى معرفة طبيعة القيم ذات العلاقة بالمساجد، فالإمام

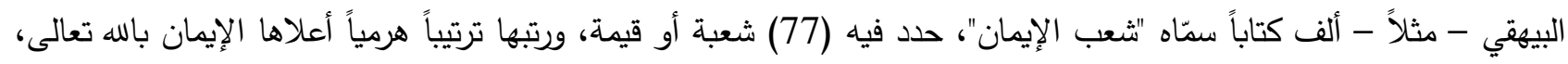

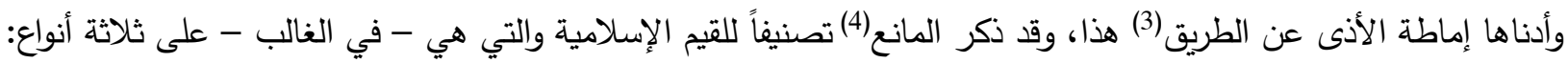

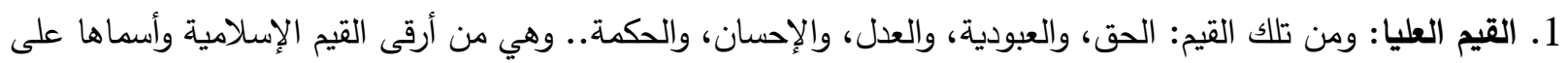

الإطلاق.

2. القيم الحضارية: ومن هذه القيم: الاستخلاف، والمسؤولية، والحرية، والمساواة، والعمل، والقوة، والأمن، والسلام، والجمال

$$
\text { وغيرها. }
$$

3. القيم الخلقية: ومنها: البر، والأمانة، والصدق، والأخوة، والتعاون، والوفاء، والصبر، والثكر، والحياء، والنصح،

$$
\text { ومنهم من حدد القيم في ستة أبعاد أمثال عبدالحميد الهاشمي وهي:. }
$$

(1) عبيد، مكانة المسجد ورسالته (ص119-137) 138).

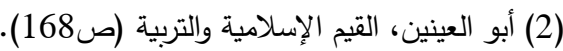

(3) عباس، نحو رؤية فلسفية تربوية للقيم في ضوء الإدلائة القرآن الكريم والسنة الشريفة (ص246).

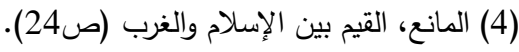

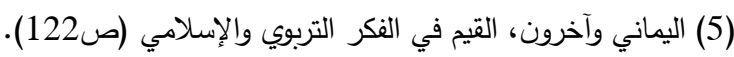




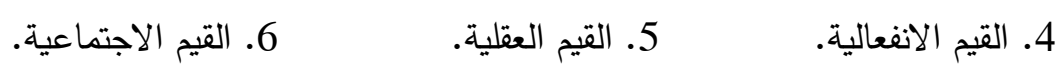

ومنهم من صنفها طبقاً لما يأتي:

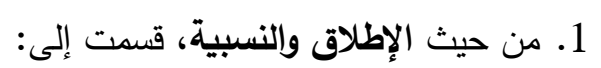

- القيم المطلقة: وهي القيم الثابتة المستمدة من القرآن الكريم والسنة الثريفة، التي لا تتغير بتغير الزمان والمكان ولا مجال للاجتهاد فيها إلا الفهم والوعي. - القيم النسبية: وهي التي ترتبط بما لم يرد فيه نص أو تصريح صريح، ومعنى نسبيتها: أنها متغيرة بتغير المواقف ولوع عبر الزمان والمكان.

2. من حيث تحقيق المصلحة: وهي ما يتعلق بحفظ الكليات الخمس، وهي: الدين، والنفس، والعقل، والنسل، والمال.

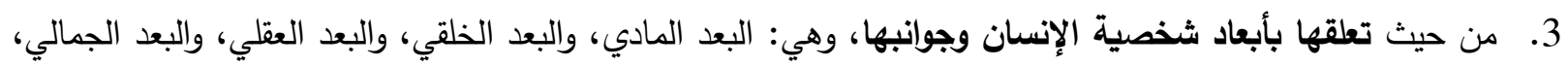

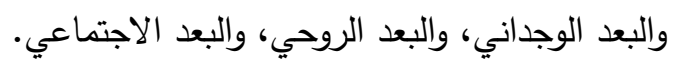

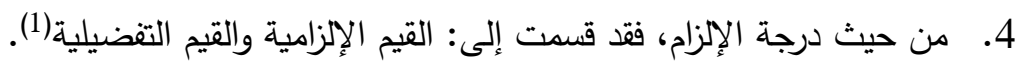

$$
\text { أما القيسي فقد قسم القيم الإسلامية لعدة اعتبارات هي: }
$$

1. النظر إلى القيم باعتبار أهميتها، وهما مجموعتان: القيم العليا أو المركزية أو الحاكمة وعلى رأسها قيم التوحيد، والقيم

$$
\text { المحكومة: وهي مجموعات القيم الأخرى. }
$$

2. النظر إلى القيم باعتبار وجوبها وعدمه، وهي القيم الإلزامية: التي تشمل الفرائض والنواهي التي يعاقب منتهكها. والقيم

التفضيلية: وهي القيم التي يكافأ عليها، لكنها لا ترقى إلى مستوى الأولى.

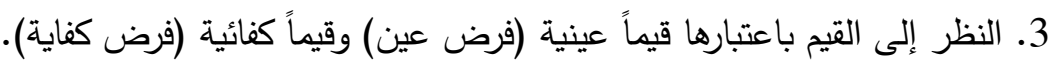

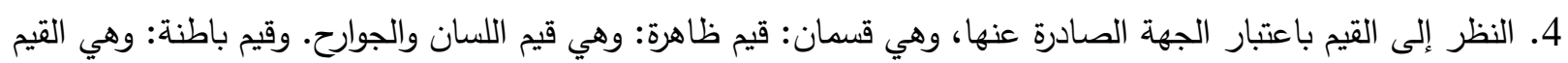

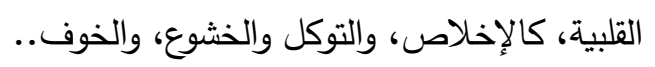

5. النظر إلى القيم باعتبار الغايات والوسائل، وتقسم إلى مجموعتين رئيسيتين هما: قيم ذاتية أو غائية، ويتوصل إليها بقيم

$$
\text { أخرى هي ما يمكن تسميته: قيماً ذرائعية أو القيم الوسائل(2). }
$$

أما علاقة القيم الإسلامية وتصنيفاتها بالمساجد، فيمكن القول: بأنها تمثل علاقة تشاركية وانسجام؛ ذلك أنكان أن القيم

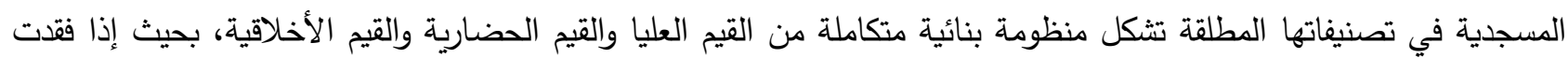
حلقة قيمية واحدة من إحداها أخلت حتماً بالجوانب الأخرى؛ فالإيمان - مثلاً - وهو من القيم العليا لا يمكن أن يأخذ مكانه

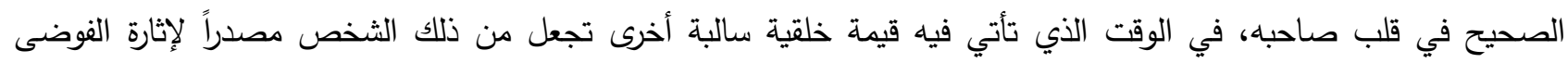

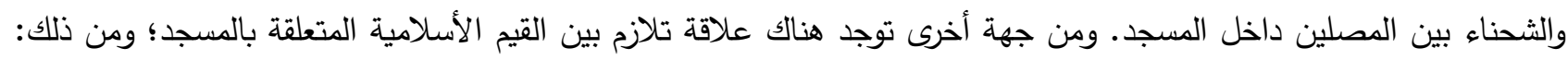
صلاة الجماعة - مثلاً - في المسجد خمس مرات في اليوم الواحد، هي قيمة إيجابية يلزم منها دفع قيمة سلبية أخرى تتمثل في توني

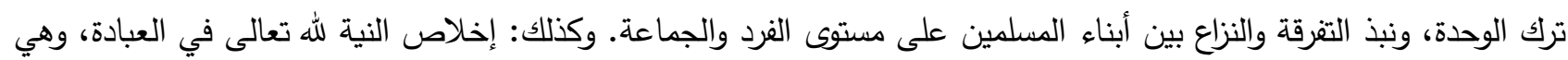

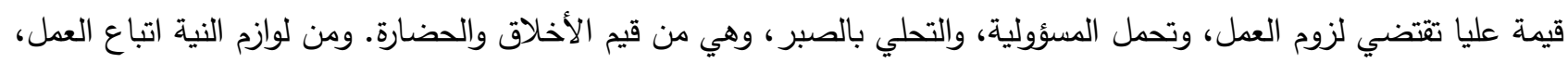
لقوله

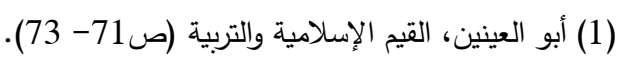

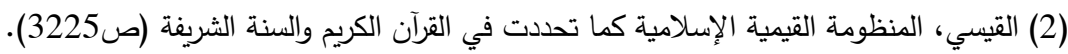


وقد تربط بعض القيم المتعلقة بالمساجد علاقة طردية، ويبدو ذلك في: أنه كلما حافظ المسلم وازداد اهتمامه بالذهاب إلى في

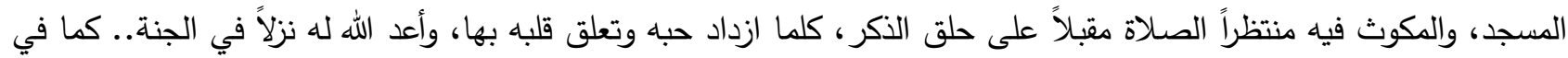

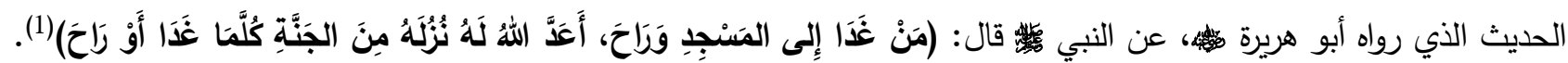
والحديث فيه: أن المداومة المضطردة في الذهاب إلى المسجد يفيد دوام النُّزُل - أي الضيافة وراه - وثباتها لصاحبها.

المطلب الرابع: أشكال القيم المتعلقة بالمساجد الواردة في السنة النبوية يرى الباحث أن طبيعة القيم المتعلقة بالمساجد لا تخرج في حقيقتها أو شكلها عن الأطر القيمية والتصنيفات التي أشير

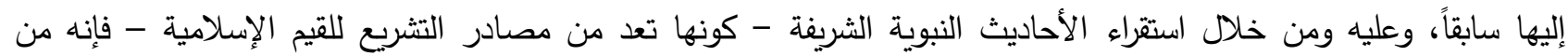
الممكن التعرف على طبيعة القيم المسجدية التي جاءت على صورة آداب وأخلاق عامة تتناسب مع الحال والمواقف التي سيقت

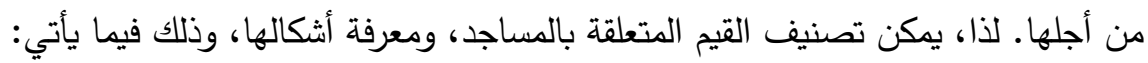

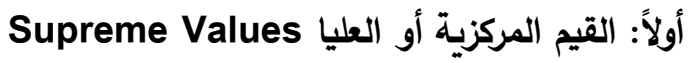
وهي القيم الإيمانية الحاكمة التي تتقاد إليها جميع القيم المحكومة مما هو أدنى منها، بحيث تؤثر على عملية سير القيم الأخرى مما هو سواها، وانضباطها وفقاً لها من حيث القبول أو الرفض.

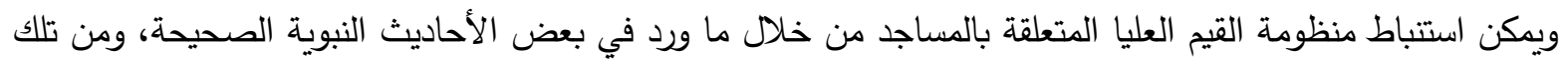
القيم ما يأتي:

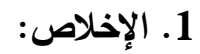
والإخلاص يتعلق بالنية التي محلها القلب، وهو الأصل الذي يكون عليه مدار الأعمال من حيث القبول أو الرد. ومما

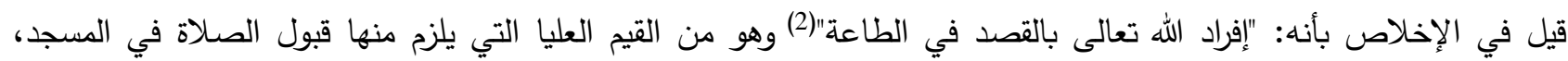

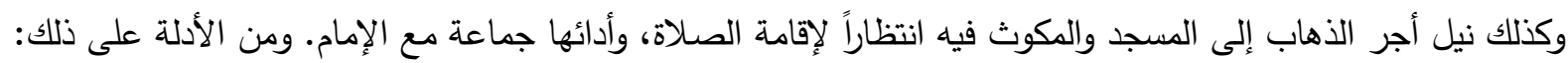

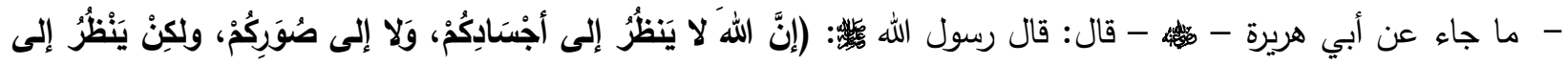
قُلُوكُمْم)(3). جاء في المنهاج: "أن الأعمال الظاهرة لا يحصل بها التقوى، وإنما تحصل بما يقع في القلب من عظمة الله

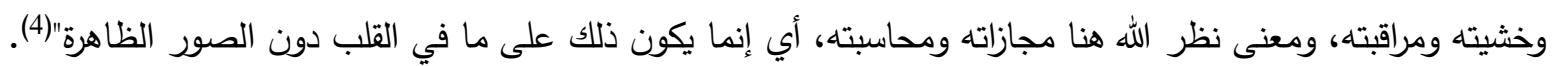

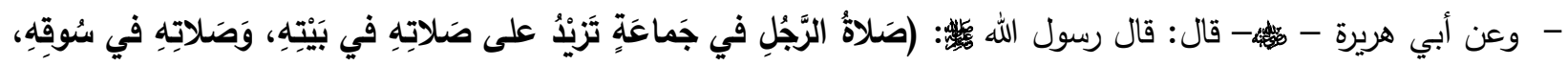

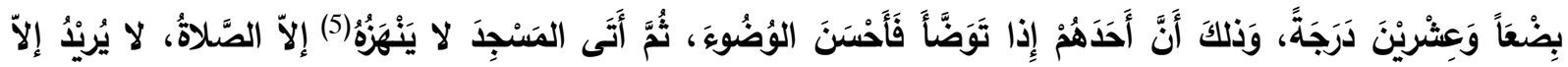

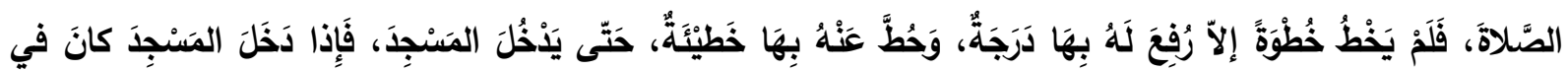

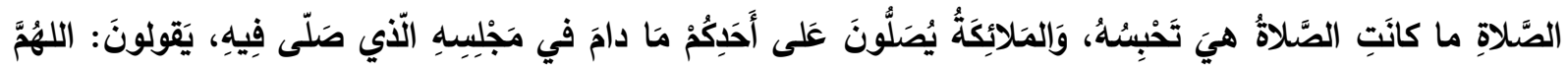

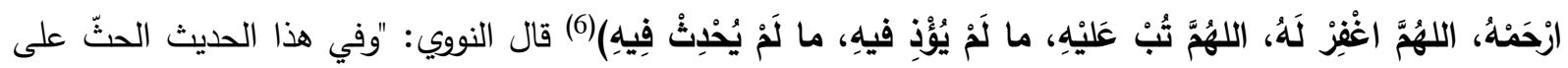

(1) متفق عليه. [البخاري: صحيح البخاري، الأذان/ فضل من غدا إلى المسجد ومن راح، 133/1: رقم الحديث 662]. [مسلم: صحيح مسلم، المساجد

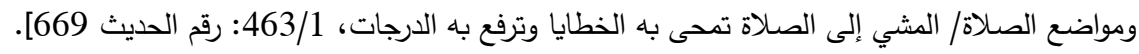

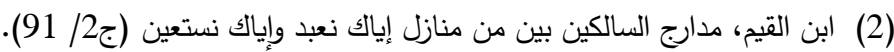

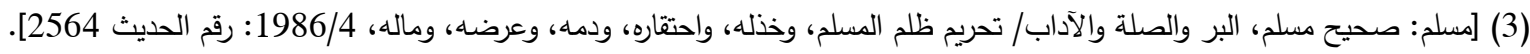

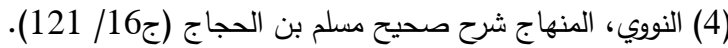

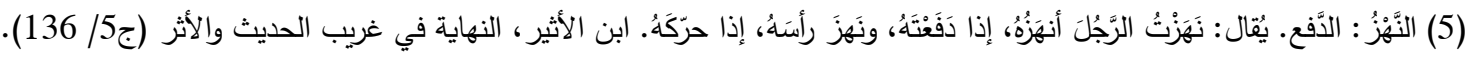

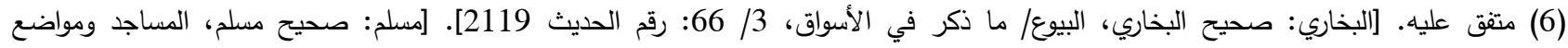

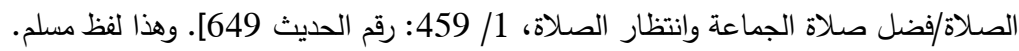


الإخلاص في الطاعات، وأن تكون متمحّضة لله تعالى"(1) وبهذا يتبين من الأحاديث المذكورة: أن الإخلاص من القيم العليا

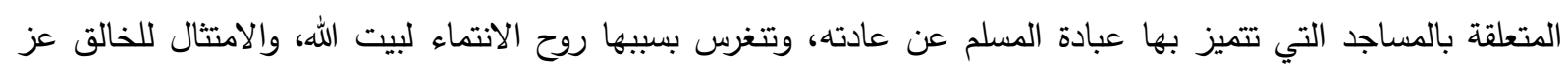

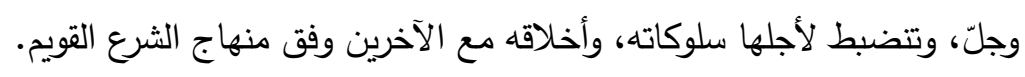

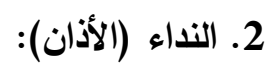

وهو الخطاب الإعلامي والثعار العام الذي ينطوي على حقيقة الإسلام في عقيدته وشرائعه. ومن الأحاديث التي جاءت

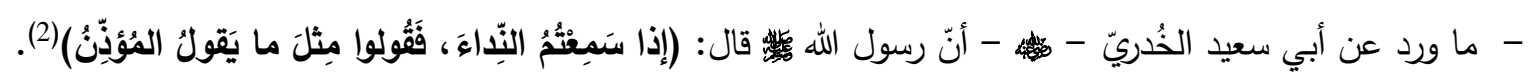

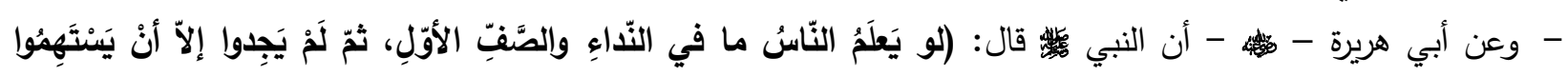

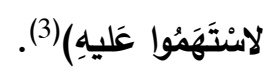
تثير الأحاديث إلى أن النداء أو الأذان يمثل شعار الدين الإسلامي، ورسالته إلى لناس، وهو المظهر العام الذي يحدد

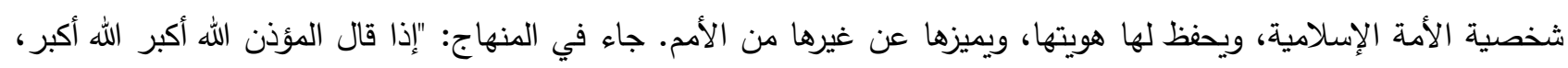

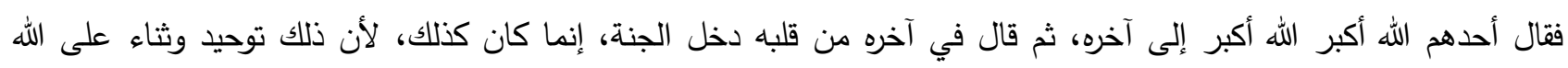

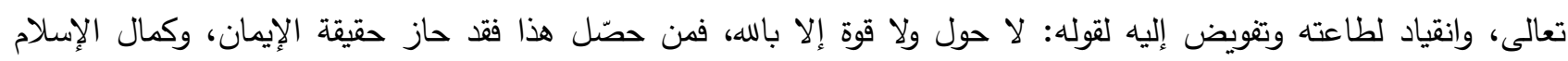

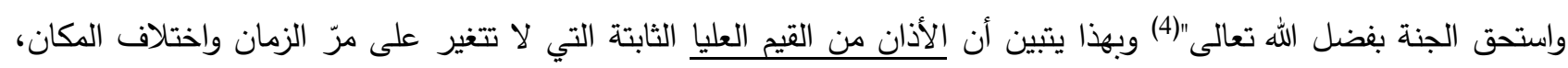

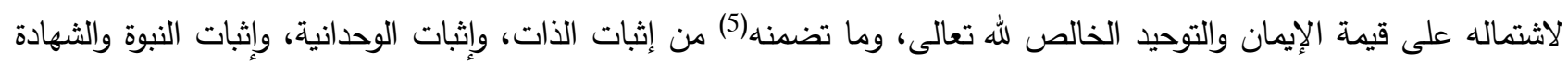

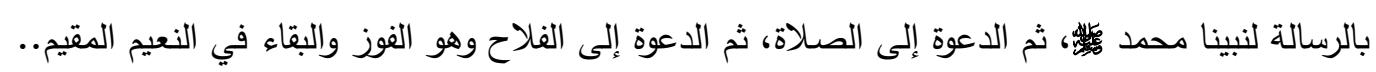
3.

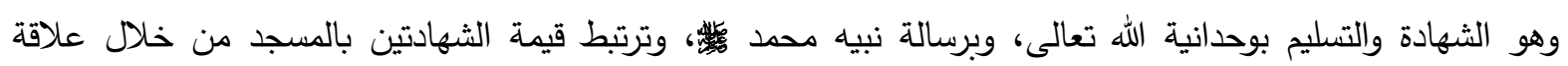

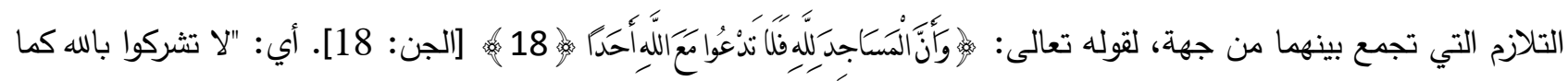
كانت اليهود والنصارى إذا دخلوا كنائسهم وبيعهم أشركوا بالله تعالى"(6)، ولاشتمال شعيرة الأذان على الثهادتين المتضمنة لكلمة

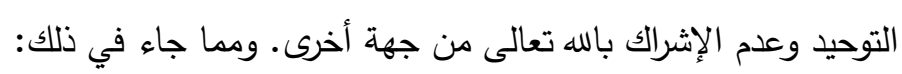

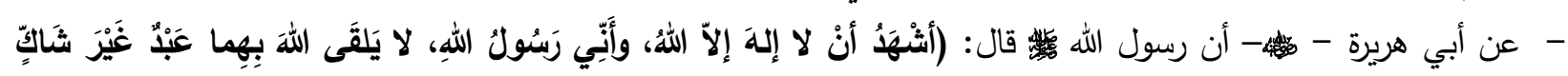
فِيهِمَا، إلاً دَخَلَ الجَنَّةَ)(7).

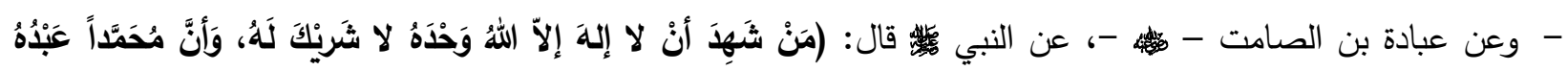

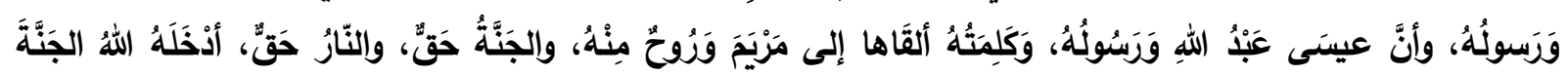

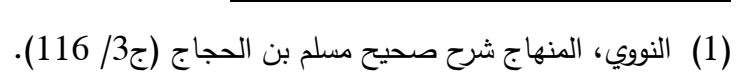

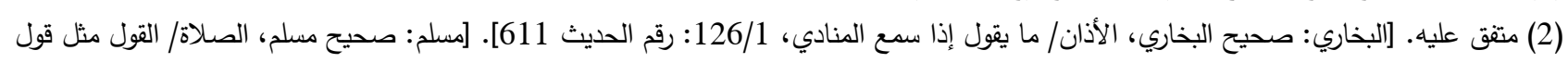

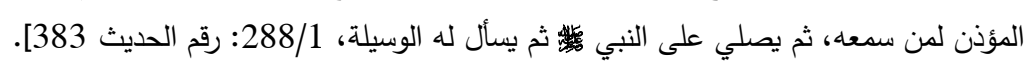

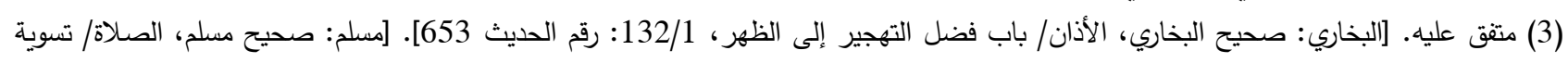

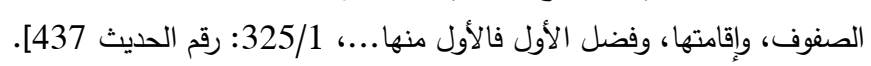

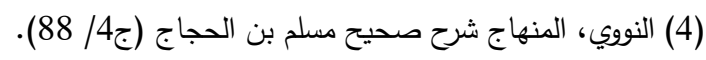

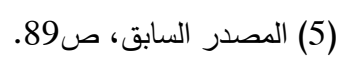

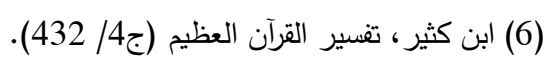

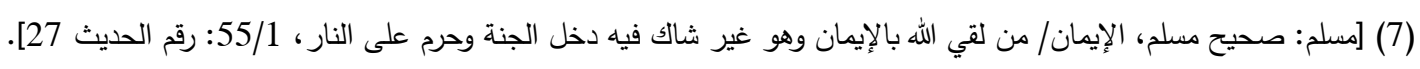




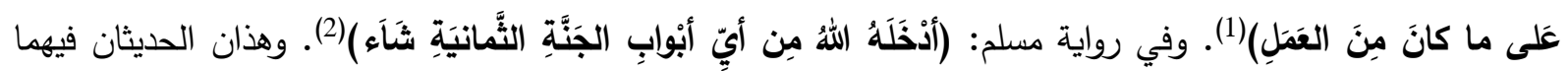

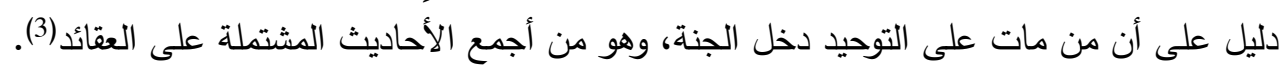

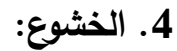

وأصل الخشوع: "هو خشوع القلب، وهو انكساره لله، وخضوعه وسكونه عن التفاته إلى غير من هو بين يديه، فإذا خشع

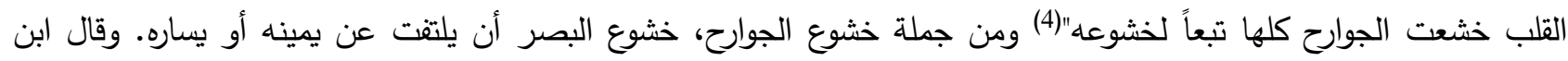

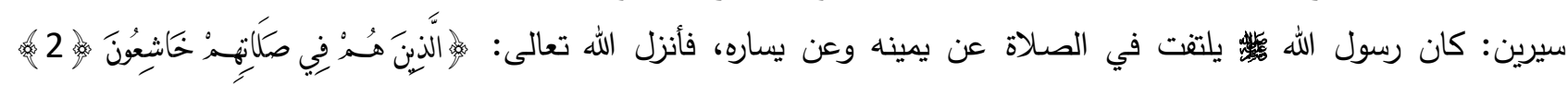
[المؤمنون: 2]. فخشع رسول الله

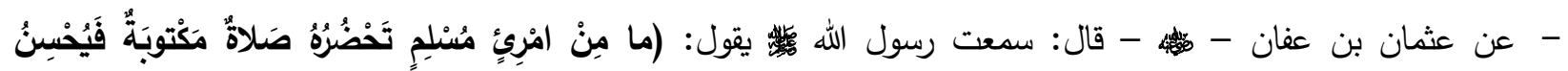

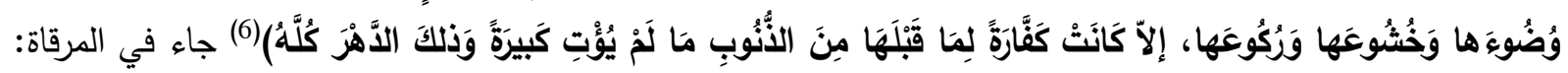

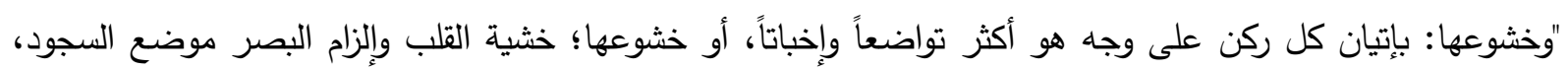

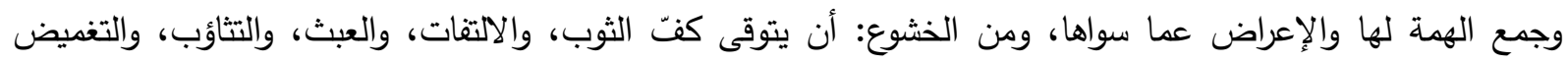
ونحوها"(7) ويؤيد ذلك:

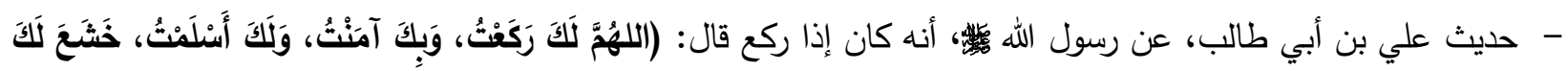

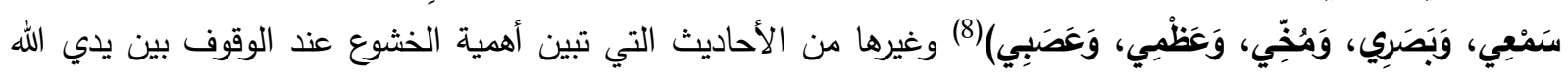

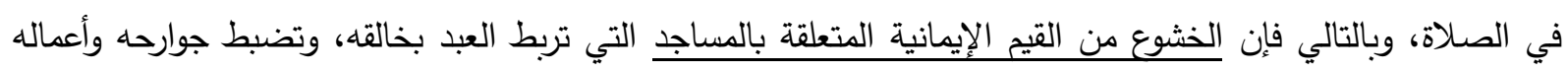
الظاهرة والباطنة، تعظيماً لحرمات الله وامتثالاً لأوامره.

5. 5. 5 إمة الصلاة:

للصلاة أهمية بالغة، ومنزلة عظيمة في الإسلام، ولقيمتها العليا من بين العبادات، فقد جعلت الركن الثاني من أركان

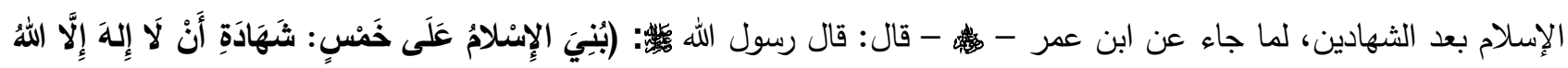

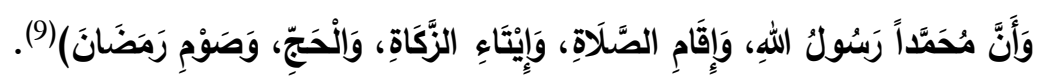

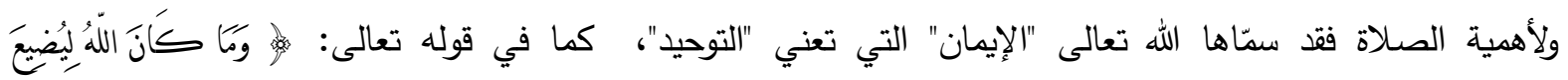

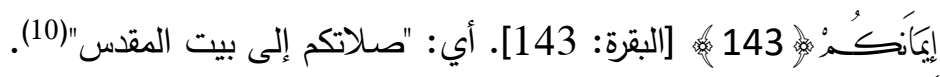

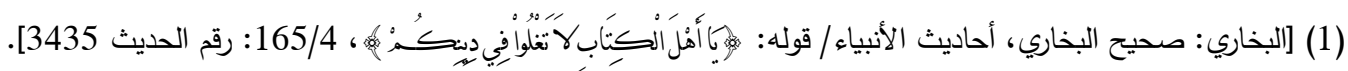

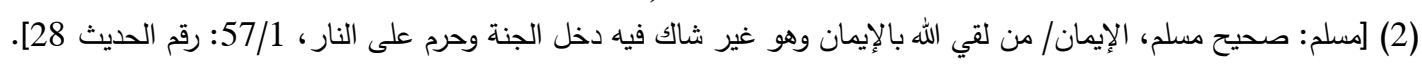

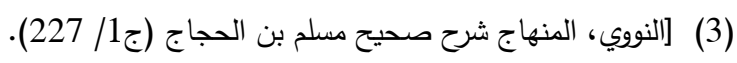

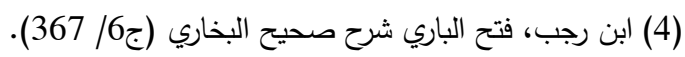

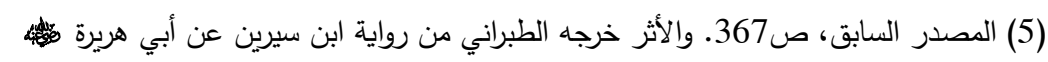

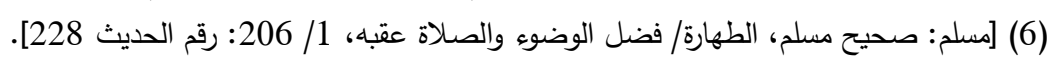

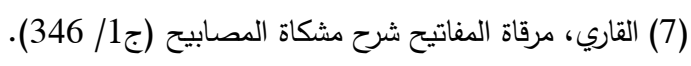

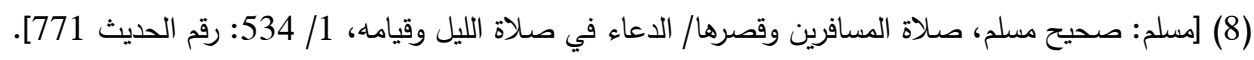

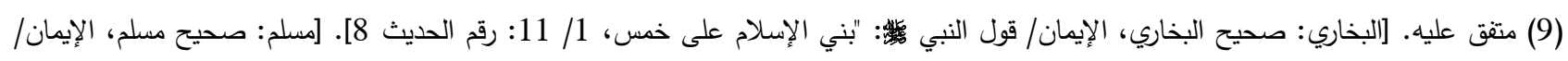

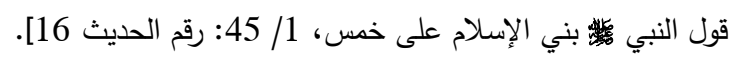

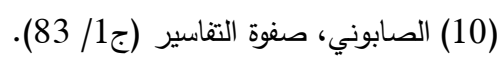


ولكون ما تتضدنه الصلاة من معانٍ وقيم راقية كقيم: التوحيد، والعبودية، والإخلاص، والافتقار ، والالتجاء، والوقوف بين

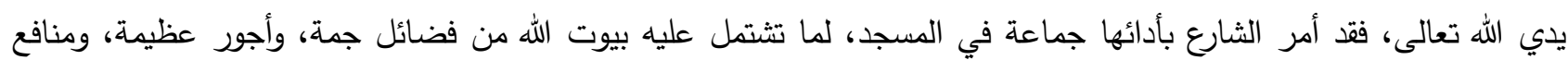
دينية ودنيوية لايمكن أن تتحقق لو كان أداء الصلاة فيما سواها. ولأهمية العلاقة التي تربط عبادة الصلاة بالمساجد، فقد جاءت مجموعة من الأحاديث تبين بعض الأحكام والقيم المتعلقة بأداء شعيرة الصلاة في المساجد، منها:

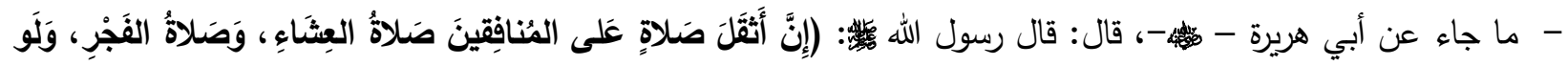

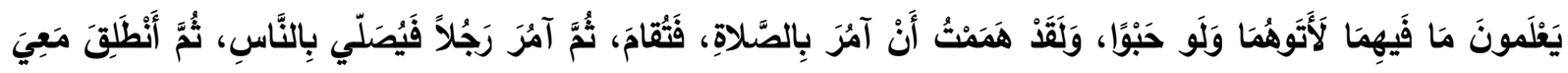

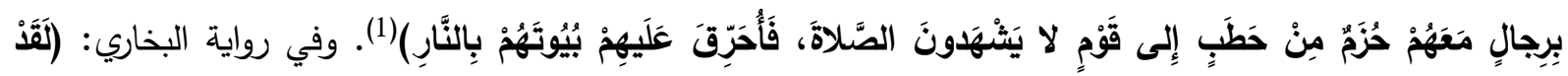

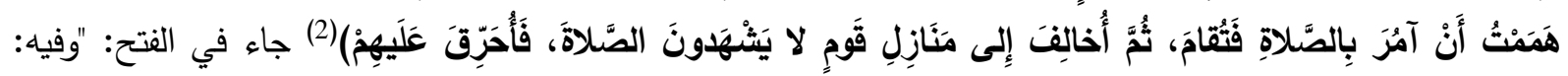

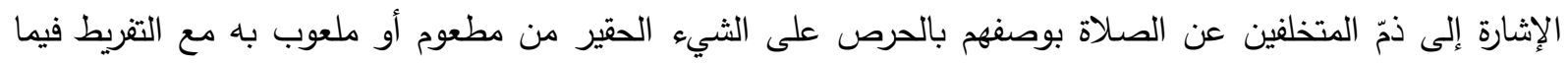

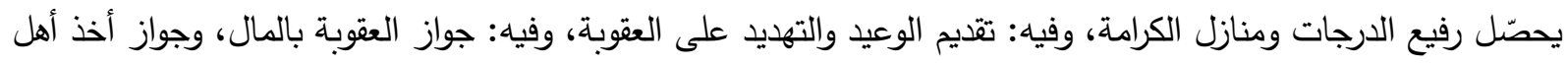

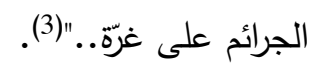

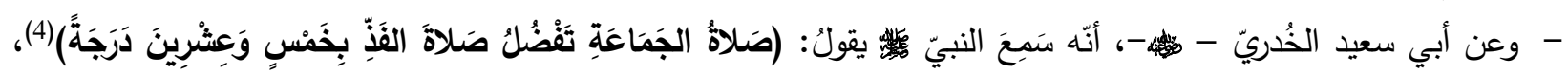

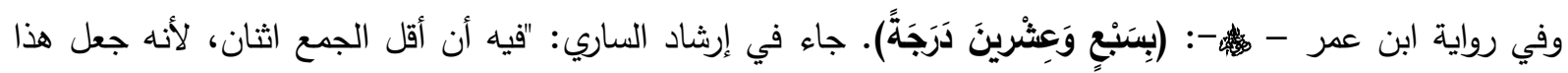
الفضل لغير الفذ - وهو المنفرد - وما زاد على الفذّ فهو جماعة"(5).

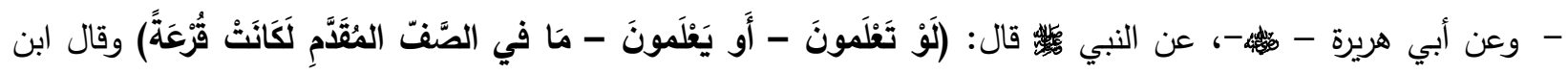

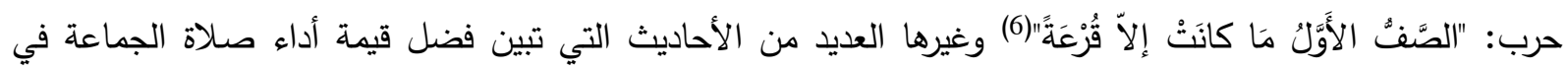
المسجد. ويستفاد من الأحاديث السابقة: هو أن الصلاة - فضلاً - عن كونها قيمة في ذاتها، إلا أنها تتطوي على قيم أخرى عظيمة وعديدة، سواء في داخل الصلاة أم خارجها، ومن بينها: قيمة التشديد في الحكم على أداء الصلاة جماعة مع الإمام في المسجد، وما يترتب على تركها من خسارة عظيمة، وكذلك: قيمة التفاضل بين قيمتين اجتمعتا من جنس واحد، فتكون الأفضلية لإحداهما دون الأخرى، كأفضلية صلاة الجماعة في المسجد على صلى صلاة الفرد، وأفضلية صلاة العتمة (الفجر والعشاء) على سائر

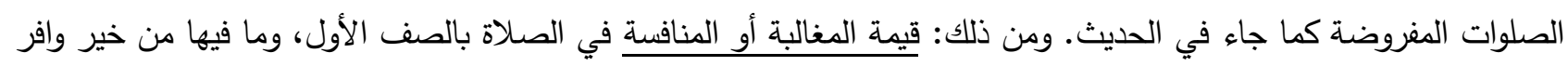
التي لو علم خيرها لكانت بالتزاحم أو القرعة عليها. 6. ملازمة الأكر:

ويقصد الباحث بملازمة الذكر: هو التقرب الدائم إلى الله تعالى من خلال إطلاق اللسان وتحريكه بالقراءة - كتلاوة القرآن الكريم - أو بألفاظ مخصوصة - كقراءة الأككار - سواء في وقت مخصوص أم مطلق، وذلك عند دخول المسجد.

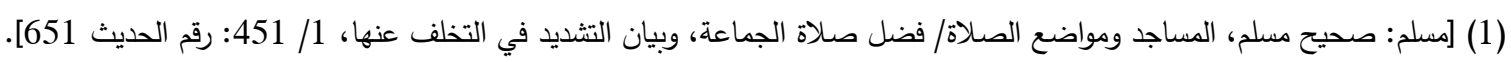
(2) [البخاري: صحيح البخاري، الخصومات/ إخراج أهل المعاصي والخصوم من البيوت بعد المعرفة، 122/3: رقم الحديث 2420]. من طريق أبي هريرة

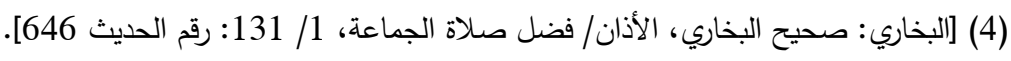

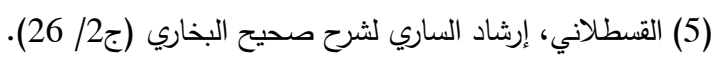

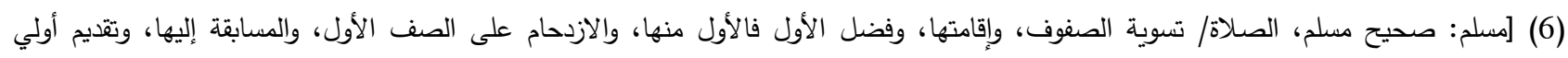


ومن الأحاديث التي جاءت في هذا الصدد:

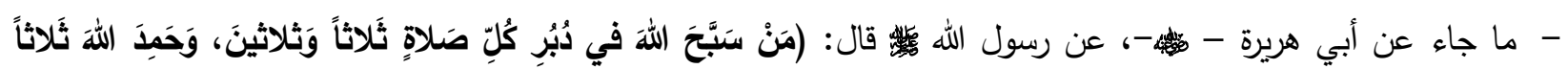

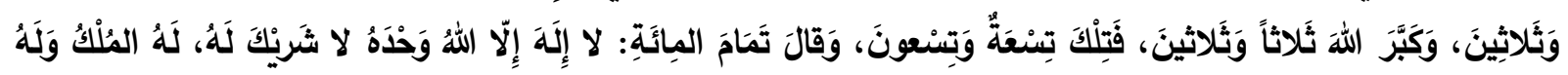

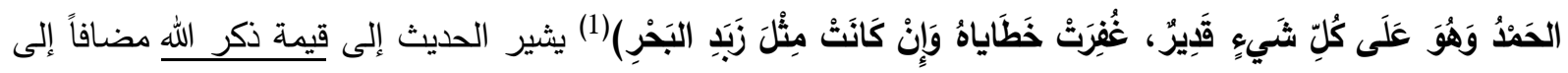

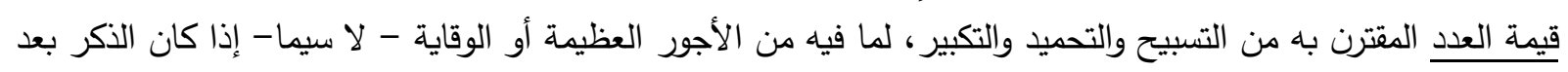
أداء الصلاة المكتوبة في بيت الله عز وجل.

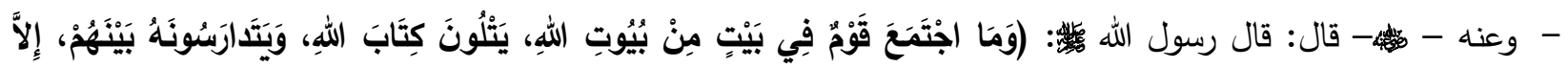

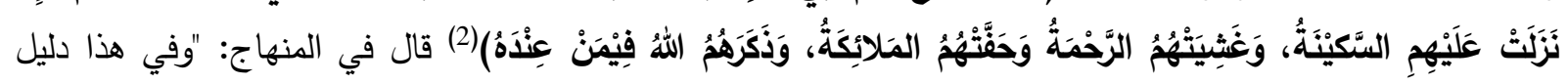

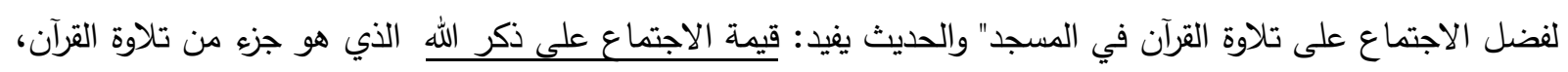

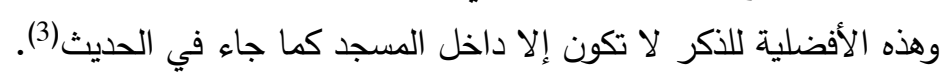

7.

والمقصود بعمارة المسجد هنا: هي العمارة المادية، وقد صنفها الباحث ضمن القيم العليا؛ كون عمارتها تعد من قيم

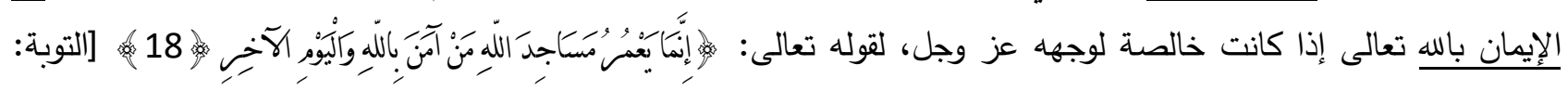

$$
\text { وقد جاء في الحديث: }
$$

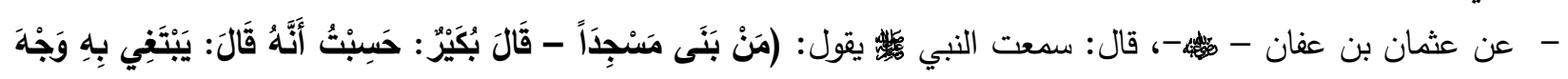

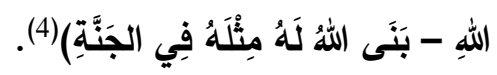

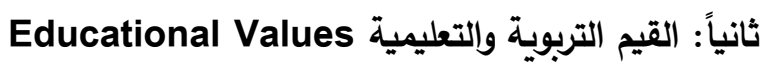

يقصد الباحث بالقيم التربوية والتعليمية: تلك المواقف والمهارات المعرفية التي تُعنى في تتمية وتهذيب الجانب الفكري والسلوكي لاى المسلم، والمستمدة من مبادئ الشرع، وذلك بهدف تعلمها وامتثالها من خلال مؤسسة المسجدئ.

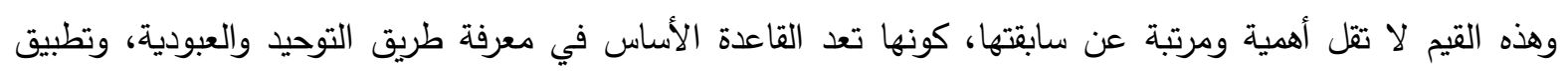

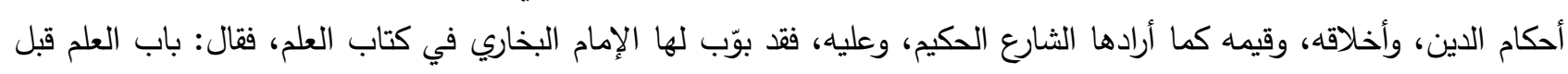

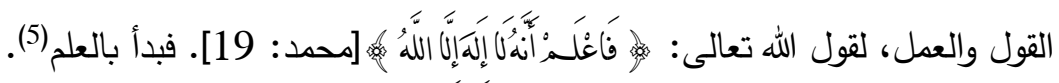

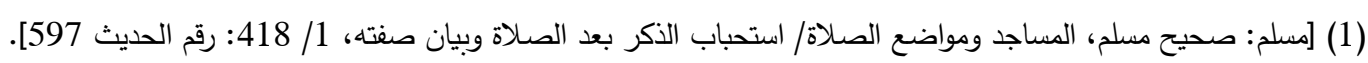

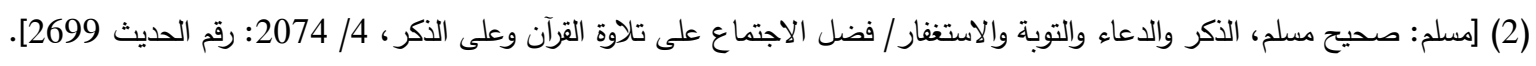

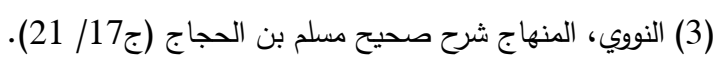
(4) متفق عليه. [البخاري: صحيح البخاري، الصلاة/ من بنى مسجداً، 1/ 97: 1287، رقم الحديث 450]. [مسلم: صحيح مسلم، الزهد والرقائق/ فضل بناء

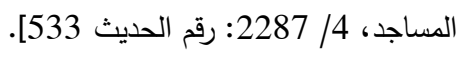

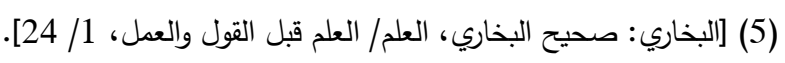


ومن الأحاديث التي تتحدث عن هذا الجانب القيمي:

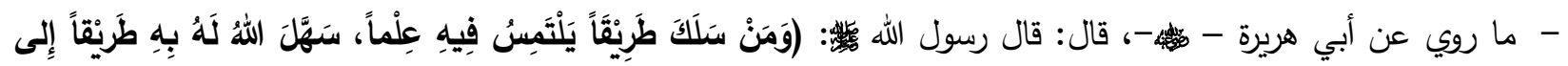

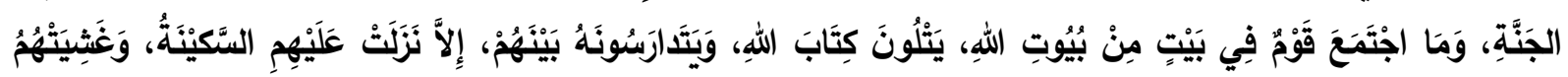

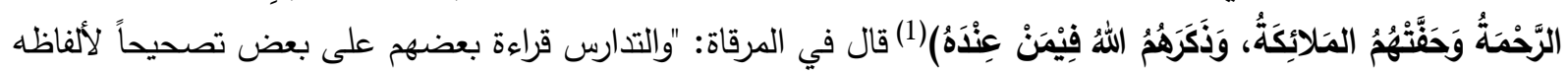

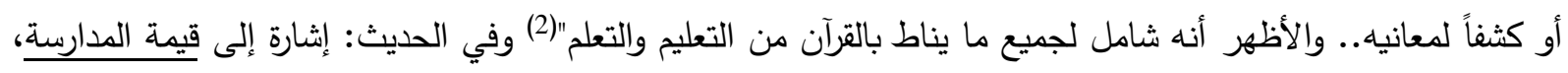
وهي تعلم القرآن وتعليمه، بدليل تفريق الحديث بين تلاوة القرآن الكريم وبين مدارسته، وهي من أرقى القيم التي تصل بصاحبها إلى أعلى درجات الرحمة، ومراتب الكمال الإنساني.

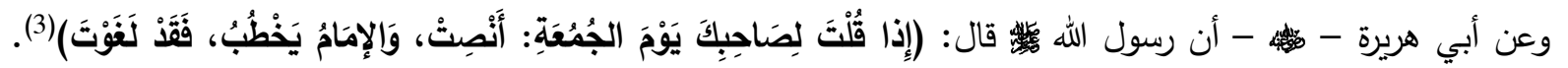

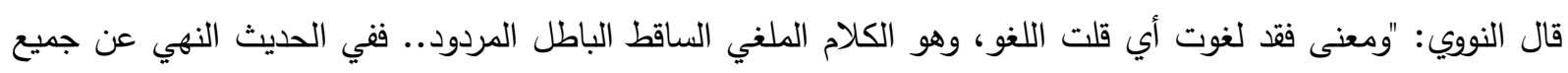
أنواع الكلام حال الخطبة"(4) وفي الحديث: إثارة إلى قيمتين مهمتين هما: قيمة السماع وهي قيمة ذاتية، وقيمة متعدية هي

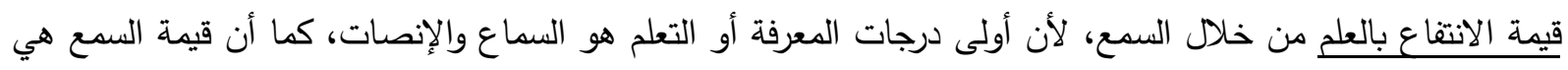

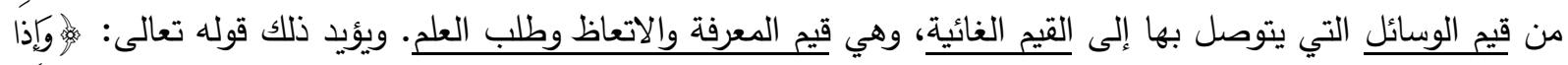

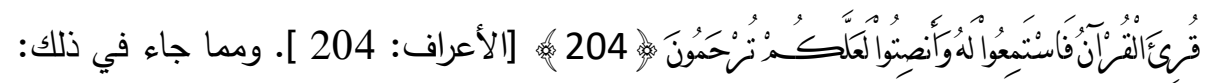

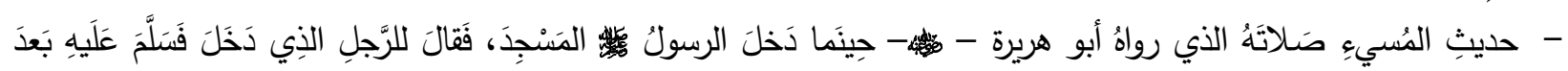

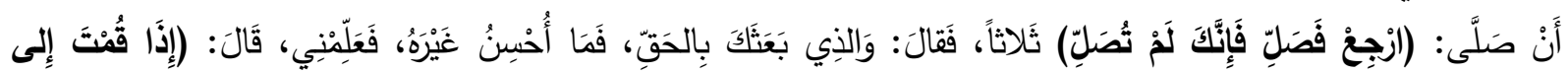

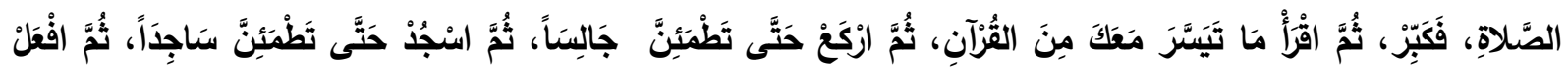

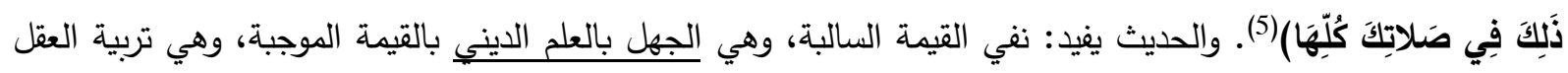

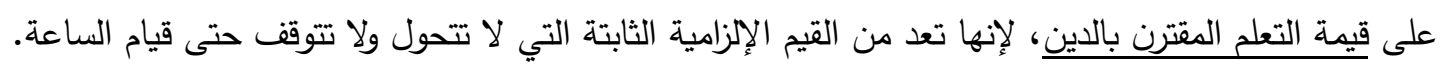

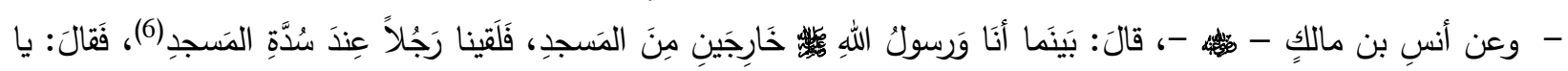
رَسولَ اللهِه مَتَى السَّاعَةِ؟ قَالَ رَسولُ اللهِ

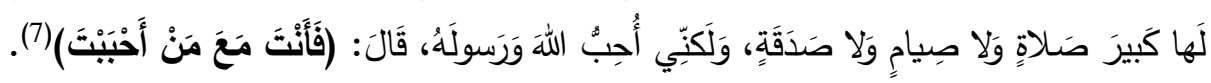

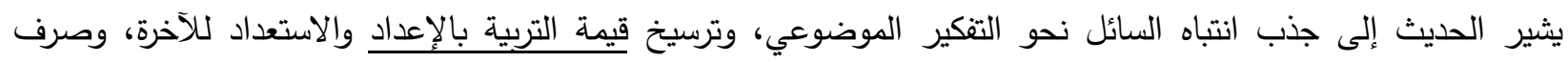

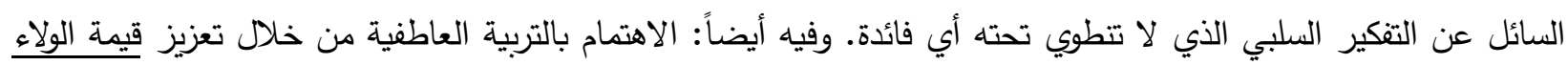

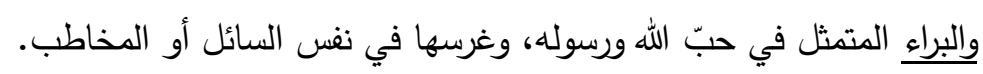

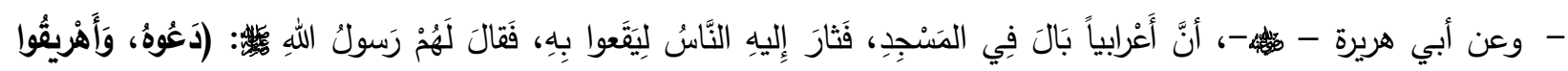

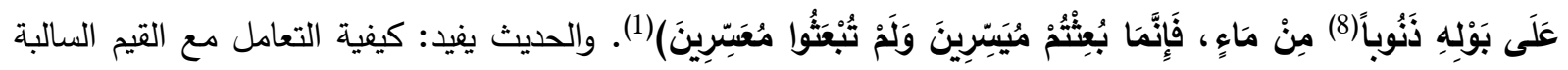

(1) [مسلم: صحيح مسلم، الذكر والدعاء والتوبة والاستغفار / فضل الاجتماع على تلاوة القرآن وعلى الذكر ، 2074/4: رقم الحديث 2699].

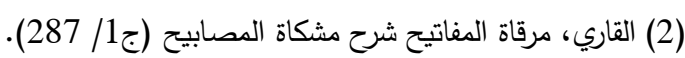

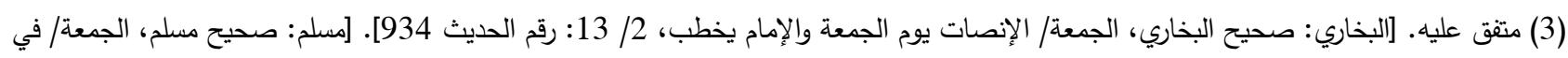

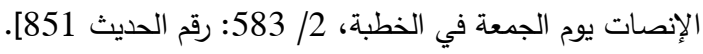

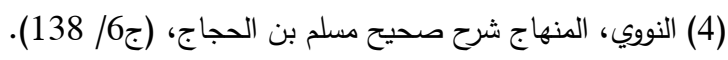

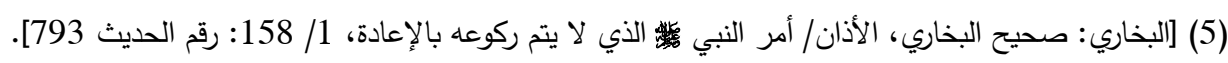

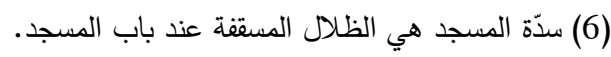

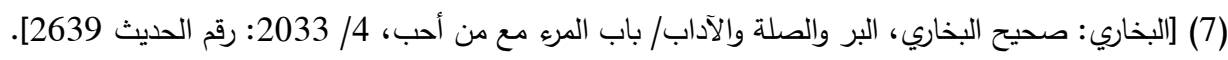

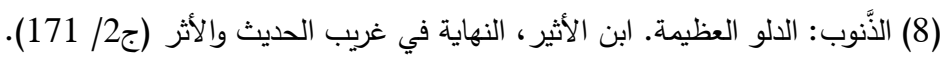


التي قد تحدث في المسجد من قبل بعض الناس، سواء بطريق القصد أم بغير ذلك، وذلك من خلال التركيز على قيم

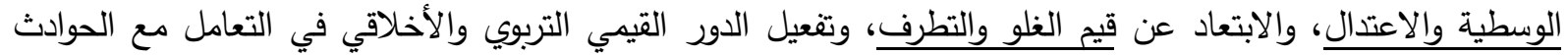
التي قد تطرأ على بيئة المسجد، وهذه المسؤولية تقوم على عاتق إمام المسجد أو من يقوم مكانه أخذاً من الحديث الثريف.

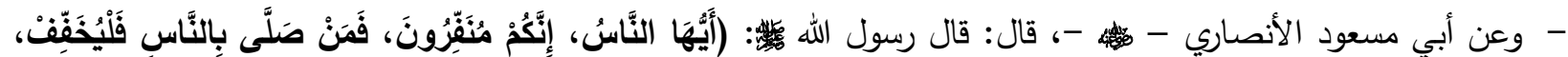

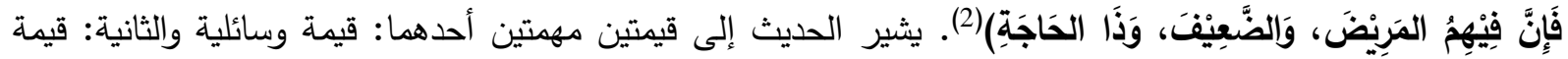
غائية؛ فأما الوسائلية؛ فهي قيمة التعلم والتنقه في أمور الدين التي بدورها تقود إلى قيمة غائية وهي قيمة الرحمة والاعتدال في تلبية مصالح الناس، ومعرفة أحوالهم، وتلبية احتياجاتهم.

Social Values ثالثاً: القيم الاجتماعية

يقصد الباحث بالقيم الاجتماعية بأنها: تلك العلاقات أو المعاملات التي تربط المسجد بالواقع المجتمي، فيما يتعلق

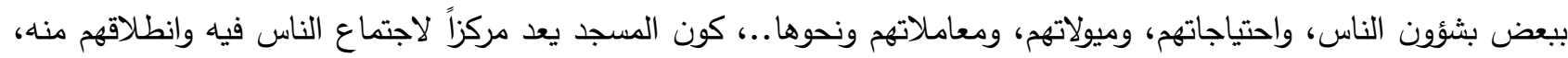
ويمثل جزءاً من النسق الديني المكون للبناء الاجتماعي.

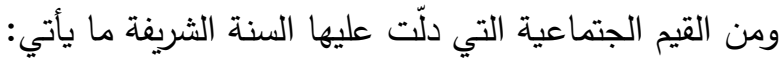

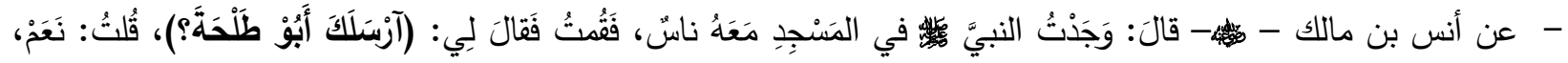

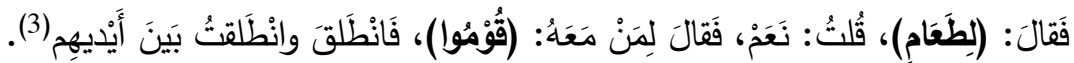

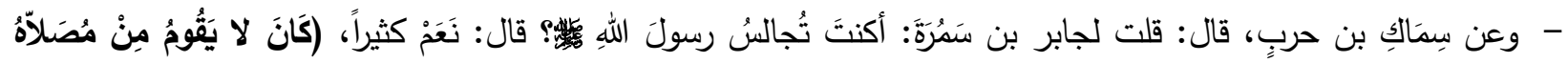

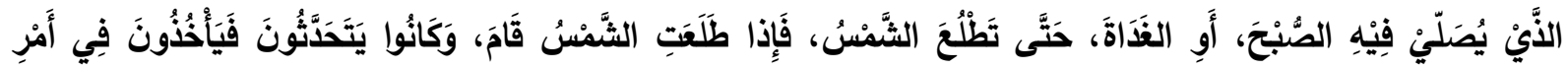

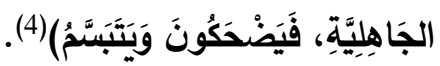

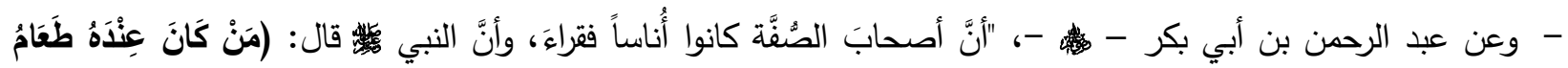

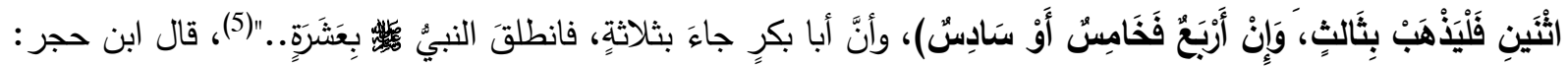

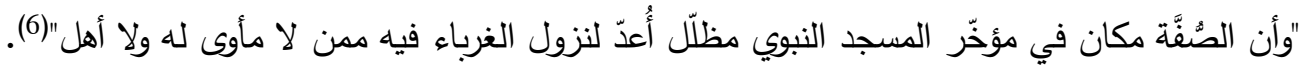

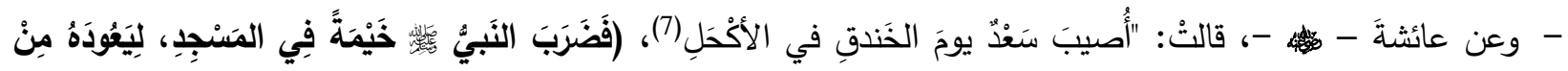

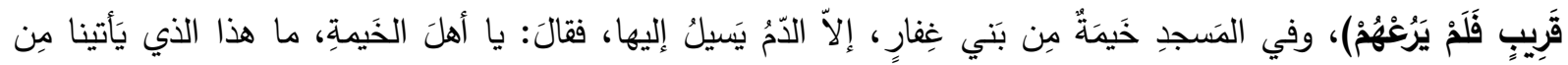

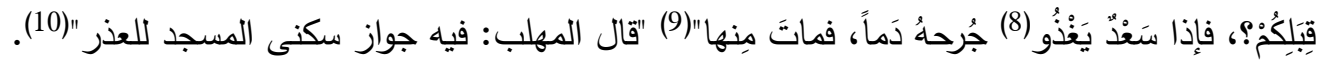

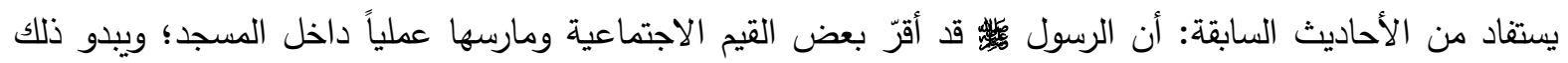
واضحاً من خلال مجالسته من لبعض لبعض أصحابه، والتحدث معهم في أمور الجاهلية، فيأخذون بالضحك وهو يتبسم فيما يعد مباحاً

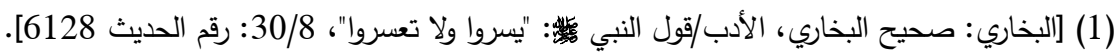

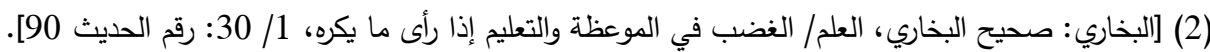

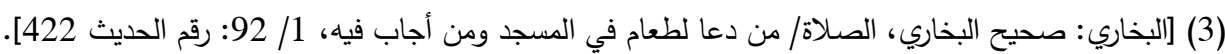

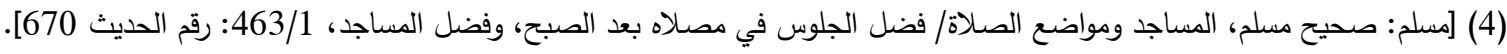
(5) [البخاري: صحيح البخاري، مواقيت الصلاة/ السمر مع الضيف والأهل، 124/1: رقم الحديث 602].

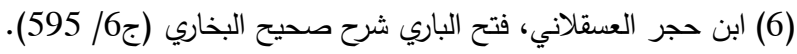

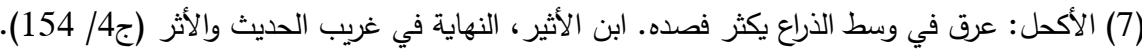

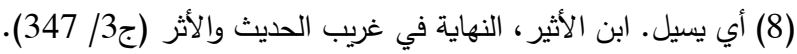

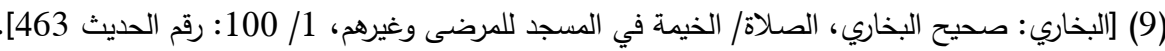
(10) ابن بطال، شرح صحيح البخاري (ج) (111) 
داخل المسجد، وكذلك مسامرته لأهل الصّفّة، وتخصيص زاوية لهم من حرم المسجد، وتفقد أحوالهم وإمدادهم بالمساعدة، ومثل ذلك

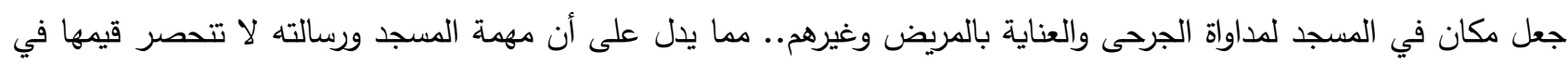

مجال العبادة فحسب، وإنما تسعى إلى ترسيخ قيمة مراعاة مصالح الناس وتلبية متطلبات المجتمع سواء من الداخل أم الخارج.

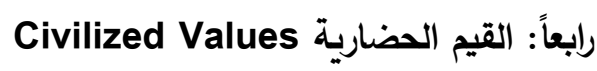

يقصد الباحث بالقيم الحضارية بأنها: منظومة المبادئ والمثل التي تحكم علاقات المصلين بالمساجد، وتوجههم نحو الالتزام بما يضفي على سلوكاتهم مظاهر النظام، والانضباط، والأخلاق، والجمال.. سواء كان في الجانب المادي أم المعنوي.

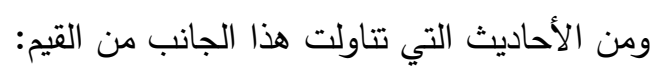

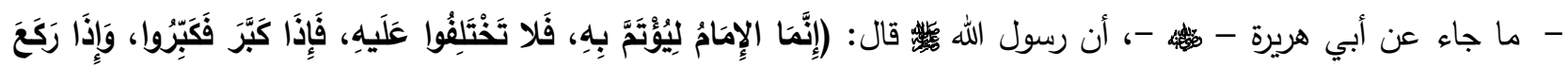

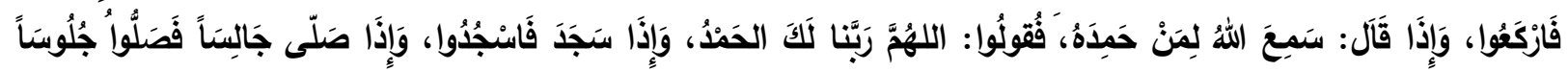
أَجْمَعُونَ)(1)

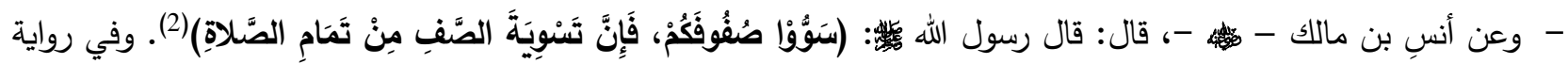

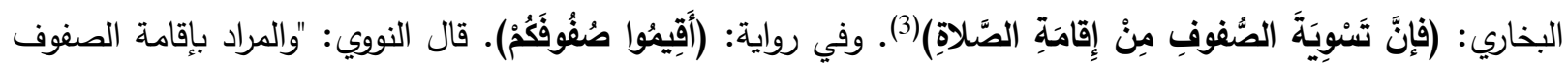

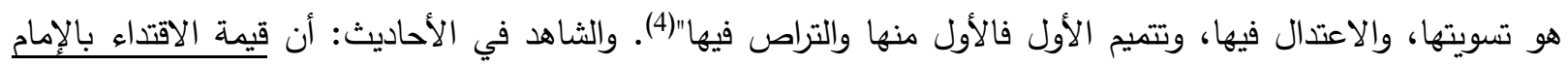

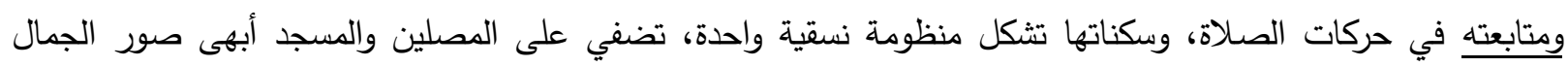

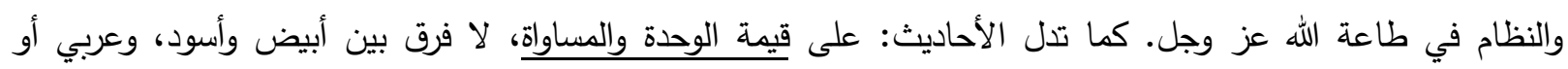
أعجمي، وغني أو فقير إلا بالتقوى. وهي - بلا شك - قيم حضارية وأخلاقية لها بعدها الجمالي والسلوكي والاجتماعي.

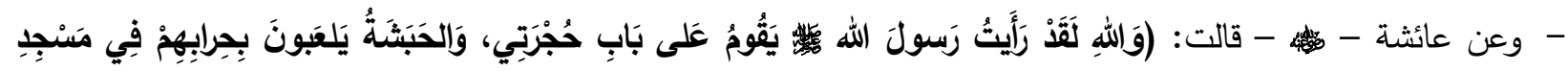

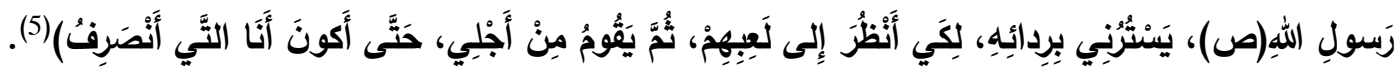

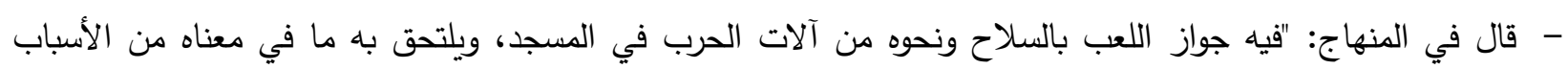

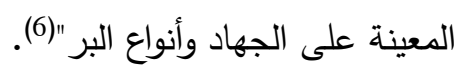
وفي الحديث دلالة على قيمة اللعب واللهو فيما هو مباح - خصوصاً - إذا كان من أجل الإعداد للجهاد ونحوه.. وهو

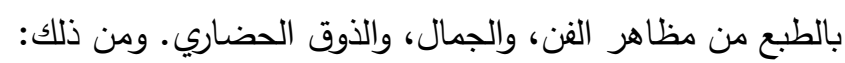

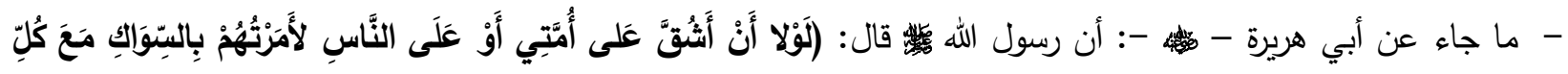
صَلاةٍ)(7). من جناء (1) متفق عليه. [البخاري: صحيح البخاري، الأذان/ إيجاب التكبير وافتتاح الصلاة، 1/ 147: رقم الحديث 734]. [مسلم: صحيح مسلم، الصلاة/ ائتمام

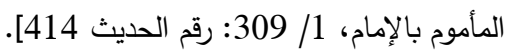

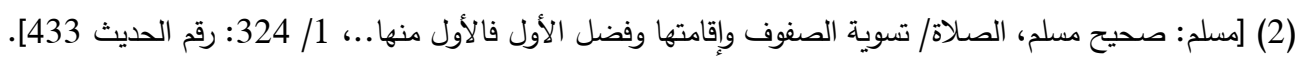
(3) [البخاري: صحيح البخاري، الأذان/ إقامة الصف من تمام الصلاة، 1/ 145: رقم الحديث 723].

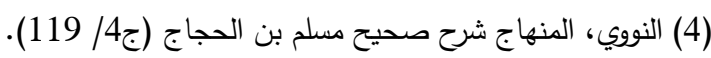

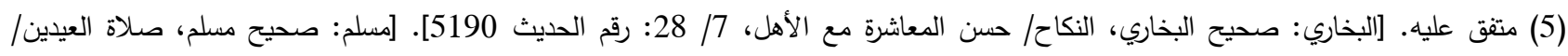

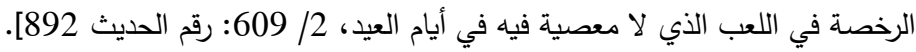

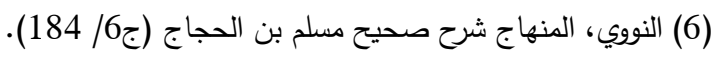

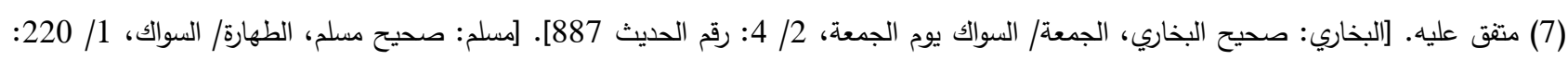
رقم الحديث 252]. 


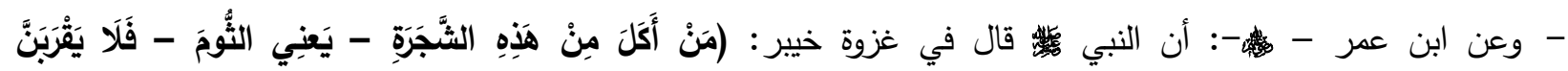
مَنْجِدَنَا)(1).

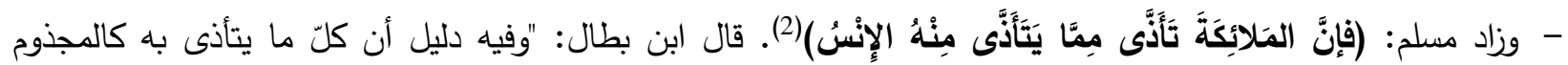

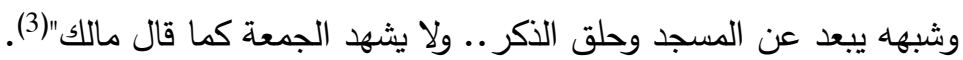
ويستفاد من الحديث: أن كل ما يتسبب بأذى المسلم داخل المسجد أو خارجه يعد من القيم السلبية التي يجب التب أن تراعى لتجتتب، كرائحة الثوم الكريهة، ويقاس عليها في زماننا رائحة الدخان ممن يمارسون التتخين، والأمراض المعدية والفتاكة، كالجذام ونحوه. وكذلك ما شهده العالم اليوم مما يسمى بمرض "الكورونا" (كوفيد 19) الذي بسبباه تعطلت موارد الحياة، وأغلقت أبواب المساجد لعدة أشهر، وسقطت بحقهم صلاة الجمعة والجماعة، لهو من باب أولى في الحفاظ على صحة الناس وحياتهم. وفي لإني الحديثين الآنغين تأكيد على قيمة البيئة الصحية للمسجد: كالنظافة، والوقاية، والسلامة العامة من الأمراض. ومن القيم العيم الحضارية

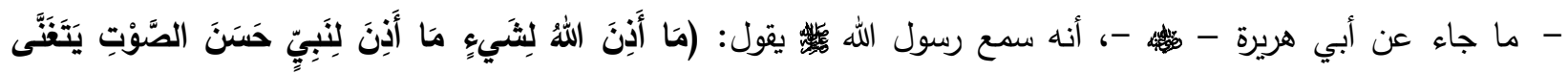

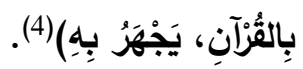
- يدل الحديث: على أهمية مراعاة قيمة تحسين الصوت بالقرآن، لما في ذلك من ترقيق للقلوب، وتأثير على النفوس.. وكم

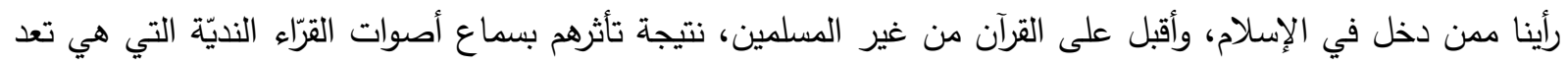
من القيم الحضارية الراقية للمساجد.

خامساً: القيم الانفعالية Emotional Values ويقصد الباحث بالقيم الانفعالية بأنها: تلك المواقف والمثيرات والاتجاهات العاطفية المتعلقة بالمساجد التي يدعو إليها الإمام أو الواعظ أو الخطيب، ومن في حكهم، بهدف التأثير وإيقاظ المشاعر لاى السامع، من خلال استعمال وسائل الترغيب والترهيب.

$$
\text { ومن الأحاديث التي جاءت في هذا الثأن: }
$$

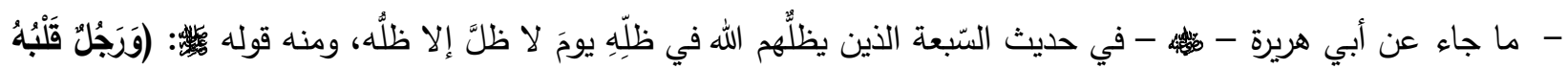

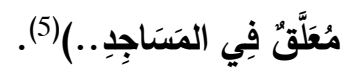

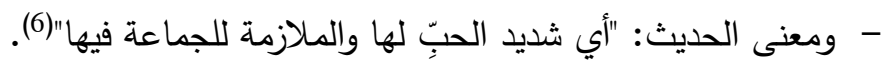

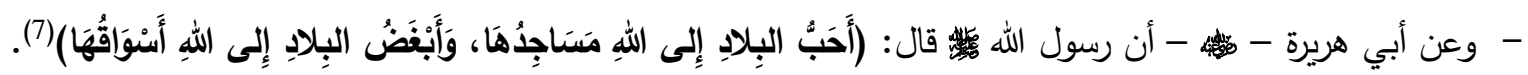

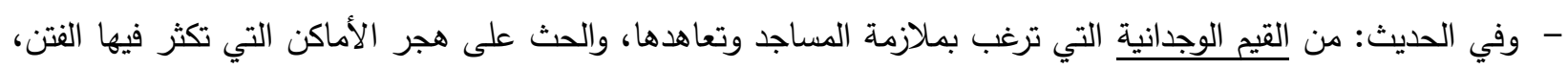
وتشغل عن ذكر الله ما لا يخفى.

(1) [البخاري: صحيح البخاري، الأذان/ ما جاء في الثوم الني والبصل والكراث، 1/ 170: رقم الحديث 853].

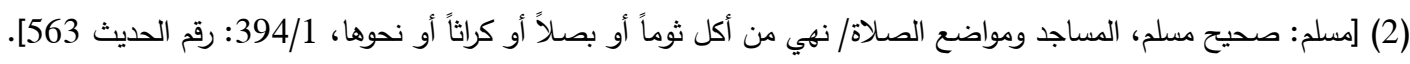
(3) ابن بطال، شرح صحيح البخاري (ج) (499/2).

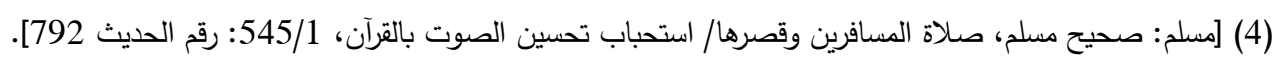

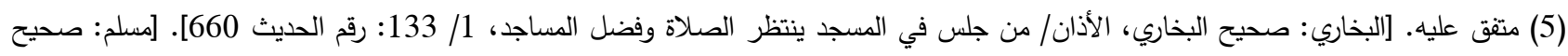

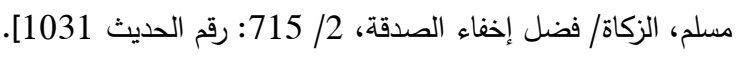

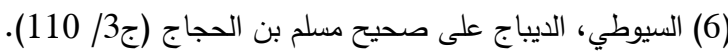




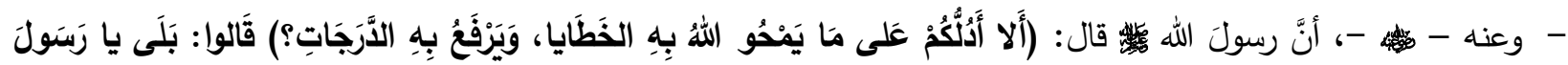

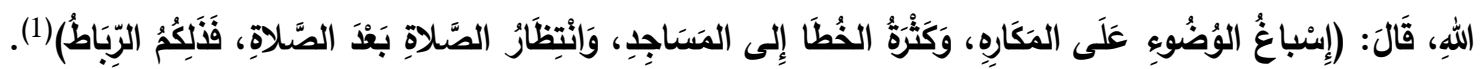

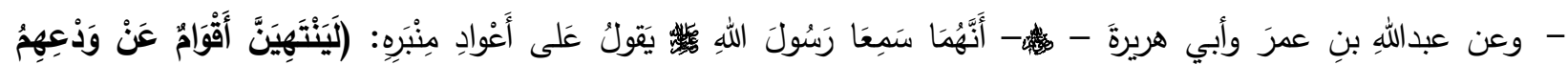

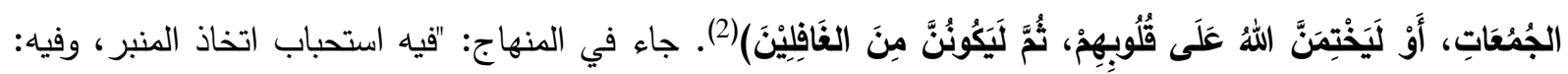
أن الجمعة فرض عين، ومعنى الختم الطبع والتغطية"(3). تثير الأحاديث السابقة إلى تتمية القيم العاطفية عند المخاطب، المتمثلة في توجيه مشاعر الحبّ، والانتماء الوجداني للمساجد من خلال ملازمتها، والمحافظة على أداء صلوات الجماعة والجمعات فيها، وكذلك إثارة مشاعر الخوف والتهديد، وذلك

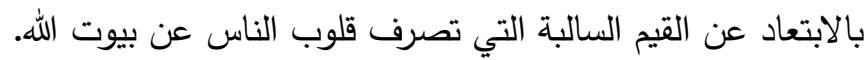

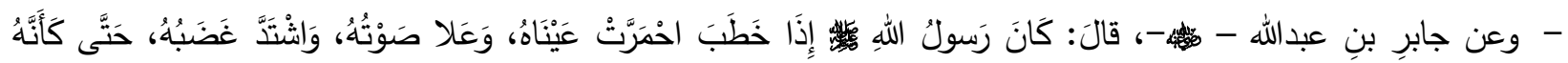

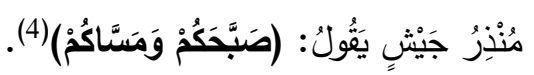

والمعنى المستفاد من الحديث: ما ينبغي أن يكون عليه خطيب الجمعة من توظيف القيمة الانفعالية والعاطفة الصادقة

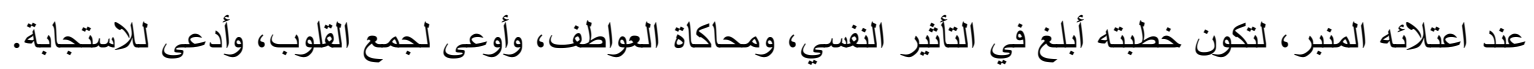
سادساً: القيم الاقتصادية والسياسية Economic and Political Values يقصد الباحث بالقيم الاقتصادية والسياسية بأنها: مجموعة الأفكار والخطط والاستراتيجيات التي يتخذها الحاكم أو ممن يقوم بتكليفه، بهدف رعاية مصالح الناس، وتلبية احتياجاتهم، وتتظيم شؤون حياتهم، فيما يصلح معاشهم على مستوى الدين والدنيا، وذلك من خلال مؤسسة المسجد ومنبره. ومن الأحاديث المذكورة في هذا الصدود:

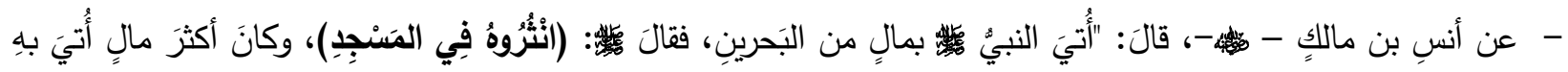
رَسولُ اللهِ

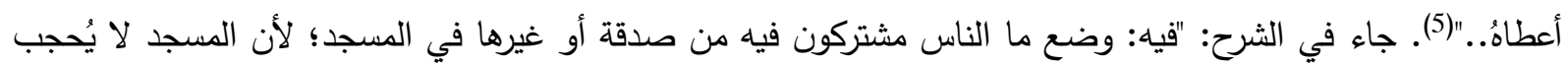

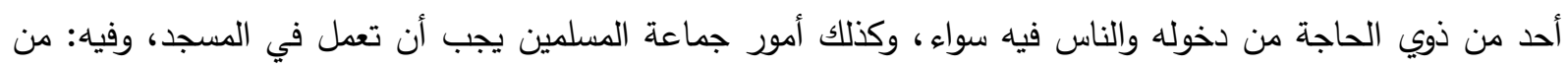
الفقه أن القسمة إلى الإمام على قدر اجتهاده، وفيه: العطاء لأحد الأصناف الذين ذكرهم الله في كتابه دون غيرهم، لأنه

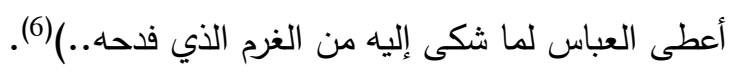

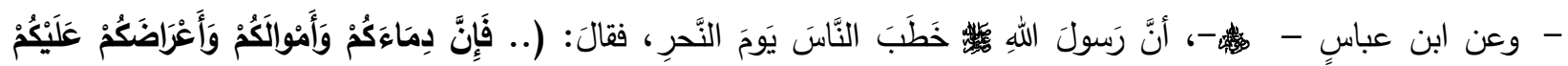

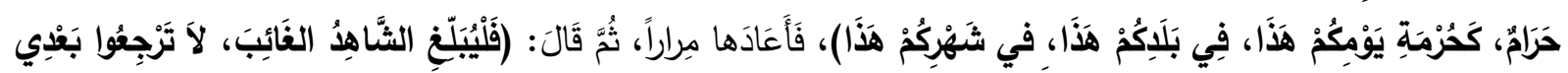

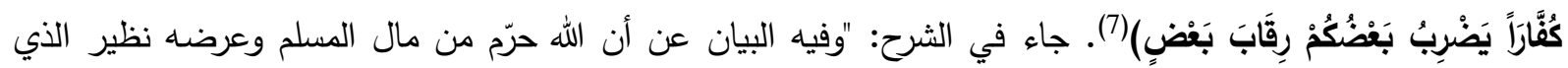

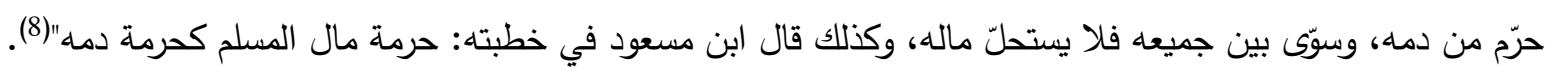


يستفاد مما جاء في الأحاديث: أن هناك علاقة قيمية واضحة تربط بين المسجد وبين الاقتصاد والسياسة، تتمثل في مراعاة القيم المتعلقة بحفظ الكليات الخمس التي تكمن في قيمة حفظ المال، وقيمة حفظ النفس، وقيمة حفظ الدين التي تسهم في صيانة مصالح البلاد والعباد، وترسيخ الأمن والاستقرار ، والارتقاء بالمستوى المعيشي للمجتمع الإسلامي. وهذا يدل على الدور

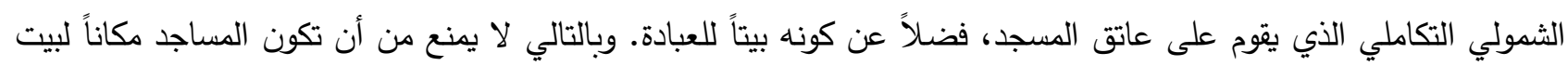

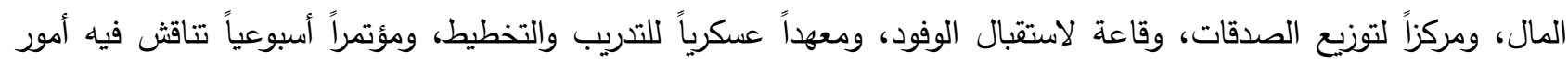
الناس الحياتية، وغيرها..

\section{سابعاً: قيم القضاء والثورى Judgment and Consultation Values}

يقصد الباحث بهذا النوع من القيم: مجموعة القواعد والمبادئ التي تمارس فيما يتعلق بالثؤون النزاعية والخصومات بين الناس، وتفعيل مبدأ التشاور القائم على قبول الرأي والرأي الآخر بين الراعي والرعية، وذلك من خلال مؤسسة المسجد.

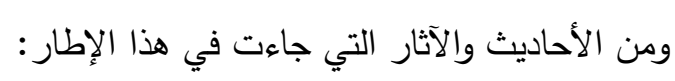

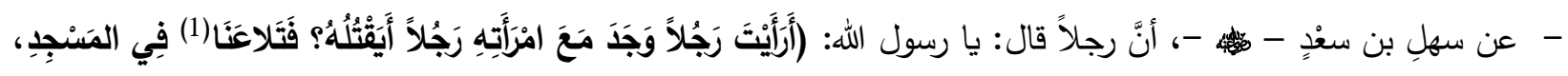

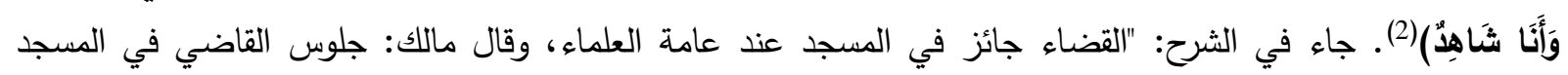
للقضاء من الأمر القديم المعمول بها.. وفيه: أن اللعان يكون في المساجد، ويحضره الخلفاء أو من استخلفه الحاكم، وأن أنساء أيمان اللعان تكون في الجوامع، لأنها مقاطع الحقوق" (3).

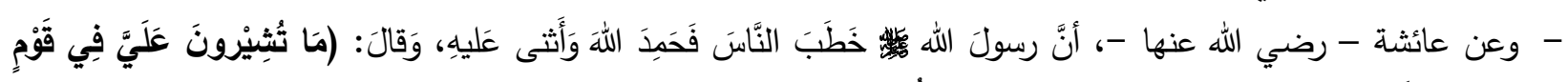

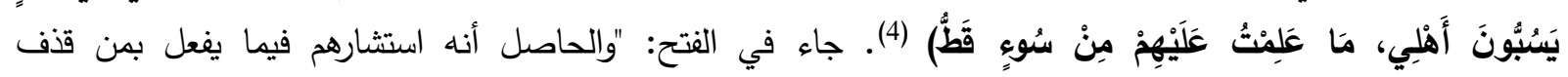

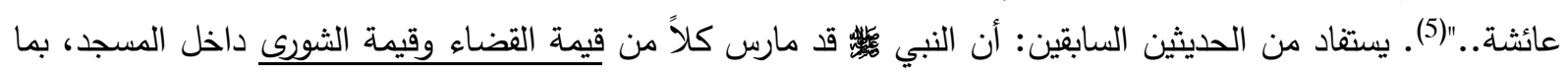

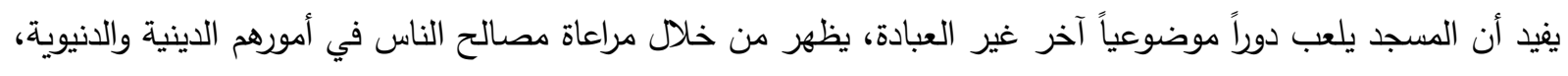

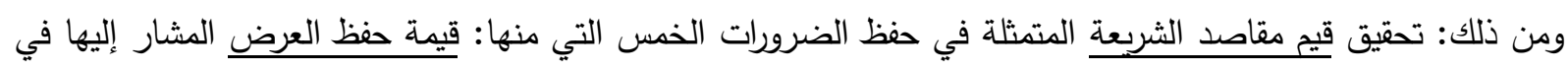
الأحاديث المذكورة. هذا، وهناك العديد من القيم المسجدية التي جاءت بها نصوص الأحاديث الصحيحة والتي يتعذر على الباحث حصرها، لضيق مساحة البحث، ولكن ما يهمنا في هذا المقام هو أن يراعي المسلمون تلك القيم ويعلموها أبناءهم، لتعود المساجد كما كانت مشعل هداية، ومركزاً للحضارة، ومنهجاً للحياة.

(1) أي الرجل والمرأة. والتلاعن: أن يحلف الزوج خمسة أيمان على صدق مدعاه بقذف زوجته بالزنا، وتحلف الزوجة خمسة أيمان على تكذيبه، وأنها بريئة

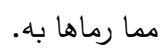

(2) [البخاري: صحيح البخاري، الصلاة/ القضاء واللعان في المسجد بين الرجال والنساء، 1/ 92 92: رقم الحديث 423].

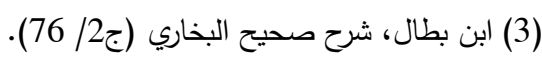

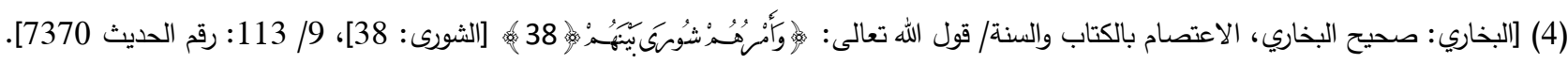




\section{المبحث الثالث}

\section{التطبيقات التربوية للقيم المتعلقة بالمساجد الواردة في السنة النبوية}

يقصد الباحث بالتطبيقات التربوبية: التوظيف العملي لمجموعة المفاهيم القيمية المتعلقة بالمساجد الواردة في الأحاديث الصحيحة، وتوجيهها في واقع الميدان التربوي المتمثل في مؤسسات (الأسرة، المدرسة، المسجد)، بغية تحقيق الأهداف التربوية التي تُعنى بتتمية الفرد المسلم وتطويره من خلال التفاعل والتعاطي معها. وسيتناول الباحث هذه التطبيقات التربوية ضمن المطالب الآتية:

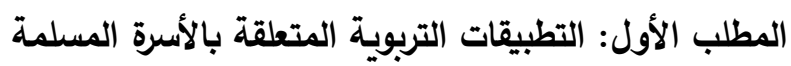
ومن أبرز هذه التطبيقات ما يأتي: الاول: التطبيقات التربه

1. الهتمام الوالدين بالأحاديث النبوية المشتملة على القيم المسجدية، وطرحها على الأبناء، وحثهم على امتثالها حفظاً وفهماً وتطبيقاً بما يتتاسب مع فئاتهم العمرية.

2. تركيز الوالدين على الأحاديث الصحيحة التي تتناول القيم الفقهية للأحكام المسجدية، والابتعاد عن الأحاديث الضعيفة إلاً ما كان في فضائل الأعمال. 3. مراعاة الآباء للقيم المسجدية التي تخاطب الجانب النفسي والانفعالي لدى الأبناء، كأسلوب الترغيب والترهيب ونحوه، ليكون أدعى للقبول والاستجابة؛ "تلك أن النفس مجبولة على حب الخير والنعيم، والنفور من الألم والعذاب، وهذا يؤدي إلى قبول التباءل القيمة وتمثلها عند المتعلم"(1). 4. تفعيل الآباء للجانب العملي التطبيقي عند ممارسة القيم المسجدية من خلال "أسلوب القدوة"، وذلك باصطحاب الأبناء معهم

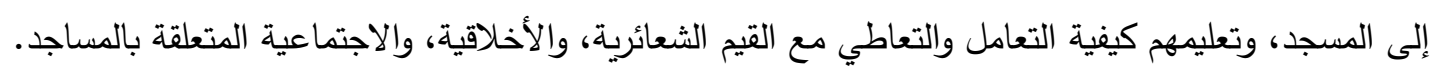

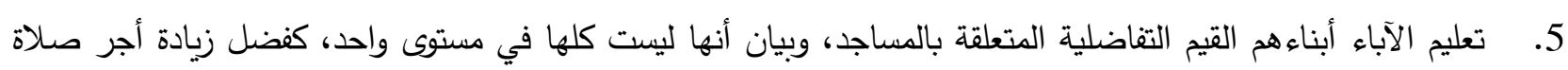

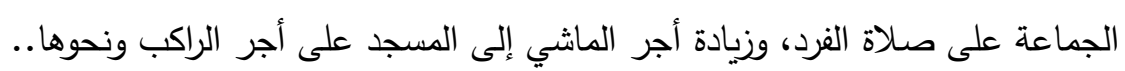
6. تركيز الوالدين على تعليم أبنائهم بعض ولى القيم المسجدية من خلاد تفعيل قيمة (التعلم بالملاحظة) أو ما يسمى بالنمذجة

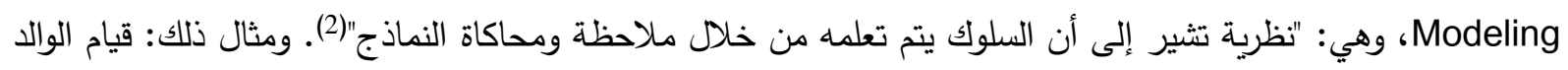

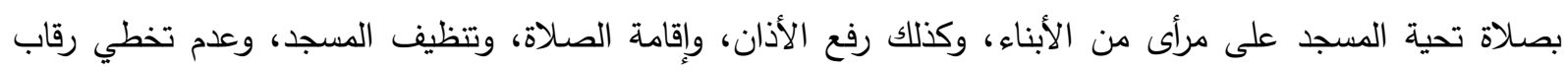

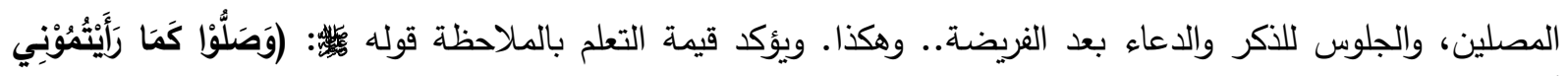
7. اهتمام الوالدين بتتمية وتطوير قيم التربية العقلية عند الأبناء، كطرح أسلوب السؤال، وأسلوب الحوار، والمناقثة، والاستماع..، وهذا بالعادة يكون من خلال مجالستهم لإمام وخطيب المسجد، من أجل تحقيق الهدف المرجو من تلك القيم. 
المطلب الثاني: التطبيقات التربوية المتعلقة بالمدرسة الإسلامية: ومن أبرز هذه التطبيقات ما يأتي: 1. تعظيم المعلم لقيمة شعيرة " النداء" أو "الأذان"، أثثاء إدارته للحصة في الغرفة الصفية، من خلال قطع الدرس، وترديد النداء مع الطلاب بمعية المؤذن، وذلك لينقل أثر تعظيم تلك القيمة إلى نفوس طلابه، ويمتثلونها في المستقبل.

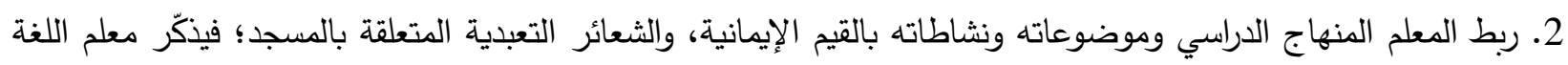
العربية - مثلاً - طلابه بأن قيمة لغتا تستمد قوتها من القيمة التعبدية المرتبطة بلغة القرآن الكريم، وكذلك معلم التربية

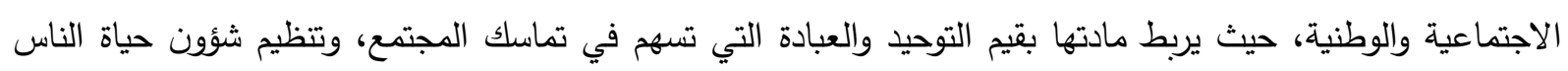
ومصالحهم في جميع المجالات.. وهو ما يمكن تحقيقه من خلال الذهاب إلى المسجد وأداء الصلاة فيه.

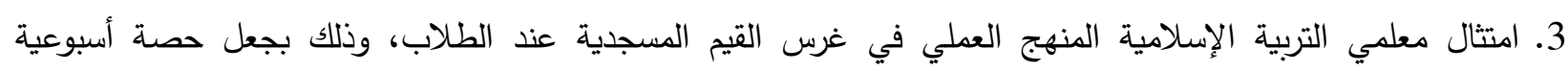

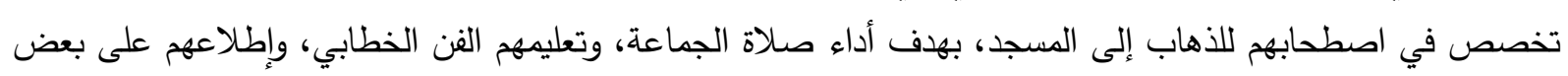
الكتب القيمة التي تحويها مكتبته.

4. قيام إدارة المدرسة بالتسيق مع وزارة التربية والتعليم بإنشاء مصلى لطلاب المدرسة، تقام فيه شعائر الأذان وصلاة

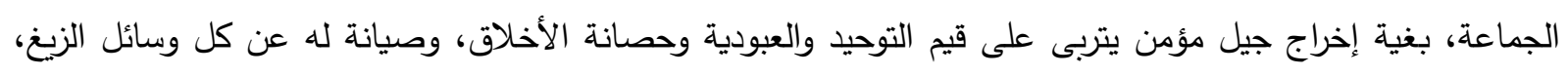

$$
\text { والانحراف، ومزالق السوء. }
$$

5. قيام معلمي المدرسة - إذا حان وقت الصلاة - بتوكيل أحد الطلاب الصغار بإقامة شعيرة الأذان داخل حرم المدرسة،

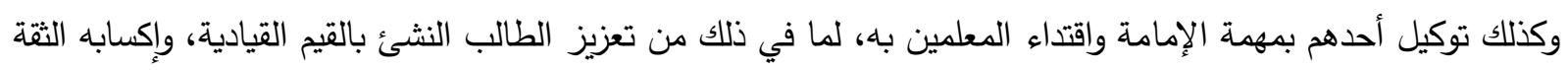

$$
\text { بالنفس على حمل الرسالة في المستقبل. }
$$

6. تركيز معلمي التربية الإسلامية على تعليم قيم ومضامين الأحكام الفقهية المتعلقة بالمساجد، والعمل على غرس تلك الفي القيم

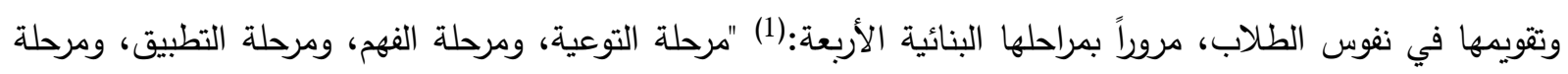

$$
\text { التعزيز ". }
$$

المطلب الثالث: التطبيقات التربوية المتعلقة بالمسجد

$$
\text { ومن أبرز هذه التطبيقات ما يأتي: }
$$

1. الكفاية الثخصية لدى إمام المسجد، ومن ذلك: أن يتحلى الإمام بفضائل الأخلاق والقيم المسجدية، وأن يمتلك المؤؤنة العلمية والفقهية الواسعة التي تؤهله للقيام بمهمة ورسالة المسجد، ليكون عوناً على تطبيق تلك القئ القيم بكل سهولة ووضوح. 2. حرص إمام المسجد أو من في حكمه على قيمة إتمام الصفوف، والتوحيد بين قلوب المصلين، وهي من القيم الحضارية

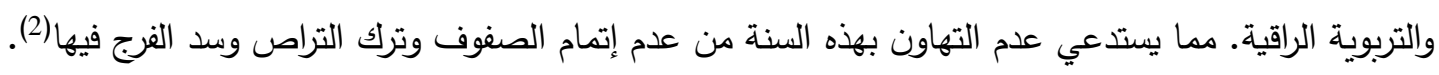
3. مراعاة إمام وخطيب المسجد للهدي النبوي أثناء ممارسته لبعض القيم التعبدية المتعلقة بصلاة وخطبة الجمعة، وذلك كقيمة

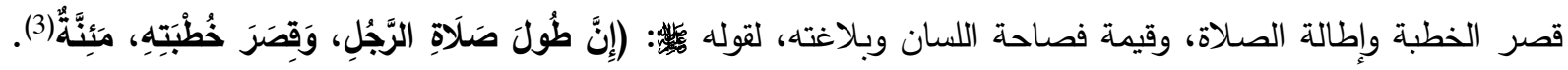

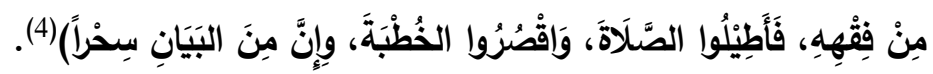

$$
\begin{aligned}
& \text { (1) الديب، أسس ومهارات بناء القيم التربوية (ص103). }
\end{aligned}
$$

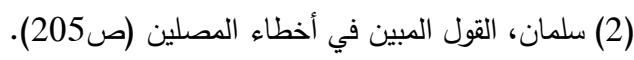

$$
\begin{aligned}
& \text { (3) (3) أي علامة. (3) (3) }
\end{aligned}
$$

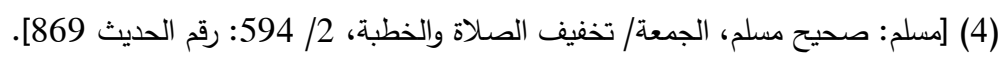


4. عمل وزارة الأوقاف والمقدسات الإسلامية على تطبيق المنهج النبوي في تفعيل تكاملية القيم وشموليتها، داخل نطاق مؤسسة المسج، بحيث يكون المسجد ذات مهام متعددة تثمل الجانب الاقتصادي، والسياسي، والعلمي، والاجتماعي،

والثقافي، والصحي.. ما أمكن ذلك، كون المسجد يعد المكان الحضاري الذي انطلقت منه تعاليم الإسلام وقيمه الراقية. 5. قيام الواعظ أو إمام المسجد بتخصيص دروس يومية أو أسبوعية يعلم فيها الناس أولويات القيم المسجدية؛ فيبدأ بالفاضل قبل المفضول، والأهم قبل المهم، فيبدأ بقيم المساجد العليا قبل غيرها، وذلك كونها تبنى عليها سائر القيم الأخرى. ويتتاول الأحكام الفقهية للعبادات قبل أحكام المعاملات، وأحكام النجاسات قبل أحكام الصلاة...، وهكذا. 6. شروع إمام المسجد بالتعاون مع لجان رعاية المساجد بتعليم وتوجيه المصلين نحو القيم التفضيلية الدكملة للقيم للعليا، كالقيم الأخلاقية، والقيم التربوية، والقيم الحضارية، وذلك بهدف منحهم القدرة على التعامل والتعاطي مع المواقف والقيم السلبية التي قد تحدث بين الناس داخل حرم المسجد. 7. مراعاة المتبرعين للقيم الإيجابية المتعلقة ببناء المساجد، كإخلاص النية لله تعالى، والابتعاد عن القيم السلبية المحبطة

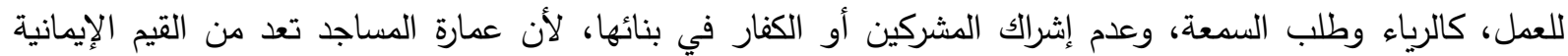

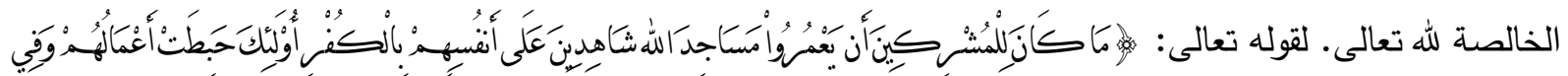

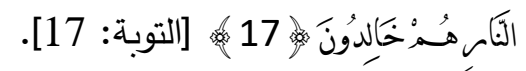
8. اجتتاب القائمين على مصالح المسجد المبالغة والإسراف في زخرفة المساجد وتزيينها كما تفعل اليهود والنصارى، وكذلك إهدار النفقات المالية بغير فائدة، مما يتتافى مع بساطة المسجد ورسالته التي جاء من أجلها.

توصل الباحثان إلى أهم الاستتتاجات الآتية: 1. إن مصطلح "القيمة" من المفاهيم الحديثة التي دخلت في الفكر التربوي الإسلامي، وقد جاء استعماله في السنة النبوية في صورة قواعد أخلاقية، وآداب سلوكية عامة. 2. لا يوجد لمصطلح القيمة مفهوم محدد عند علماء التربية، وقد اختلفت تعريفاتها، وتثعبت الآراء فيها تبعاً للفلسفة أو الاتجاه أو المدرسة التي انطلق منها أصحابها. 3. إن علاقة القيم بالأخلاق الإسلامية هي علاقة عموم وخصوص؛ فالقيم أعم من الأخلاق في اشتمالها على الجوانب المادية والمعنوية، بخلاف الأخلاق التي تصدق - في الغالب - على الجانب المعنوي. وقد يترادف المصطلحان إذا استعملت القيم المادية وتم توجيهـا نحو الخير أو الشر، فتصبح القيم المادية حينئذٍ مساوية لمعنى الأخلاق الإسلامية إيجاباً أو سلباً. 4. من أهم الأسباب التي تدعو إلى أهمية تعلم القيم هو : حفظ الهوية الإسلامية من الذوبان، وتعزيز الجانب الإيماني والتعبدي

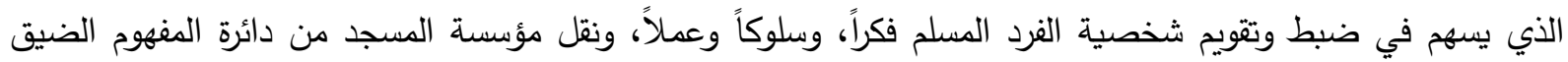
للعبادة إلى دوره الثمولي المتكامل الذي يحقق المفهوم المنهجي للحياة. 5. إن القيم المتعلقة بالمساجد ليست جميعها على مستوى واحد، وإنما تتفاضل فيما بينها، وعلاقتها بالمساجد هي علاقة تثارك وتلازم، تثكل فيما بينها منظومة بنائية متكاملة لا ينفك إحداها عن الأخرى.

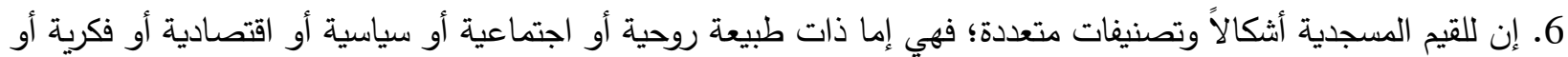
حضارية أو أخلاقية أو قضائية أو شورية.. إلخ. وهذا يدل على الثمولية التي جاءت بها رسالة المسجد. 
7. إن التطبيقات التربوية المتعلقة بقيم المساجد لها أهمية كبيرة، بحيث إذا ما تمّ مراعاتها من قبل المؤسسات الرسمية، وخصوصاً الجهات المعنية، الأمر الذي يسهم في حفظ هيبة المساجد وقدسيتها، وتخريج جيل مؤمن محصن بالقيم المسجدية، قادر على مواجهة التحديات القادمة.

ثانياً: التوصيات

يوصي الباحثان بما يأتي:

1. اهتمام الباحثين بالإطار المفاهيمي للقيم المتعلقة بالمساجد، وذلك من خلال التأصيل الثرعي لبعض المفاهيم التي تتاولتها السنة النبوية، ولم تطرق بحثاً: كالقيم السياسية، والقيم العسكرية، والقيم الاجتماعية ونحوها..

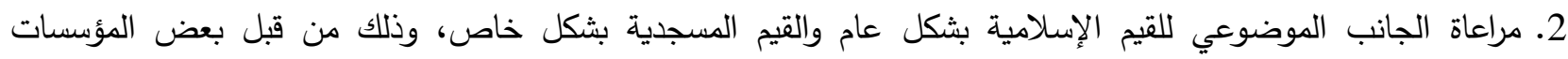

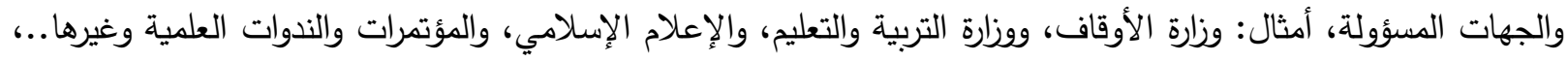

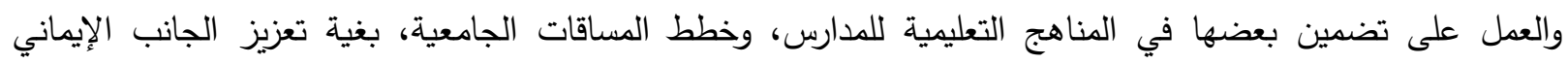
والفكري عند أبناء المسلمين. 3. عقد وزارة الأوقاف والثؤون والمقدسات الإسلامية دورات تدريبية خاصة بالأئمة، والوعاظ والخطباء حول موضوعات القيم

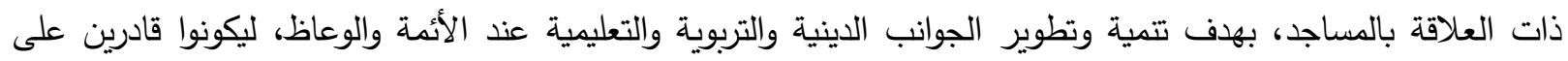
التعامل والتعاطي مع المواقف التي قد تطرأ داخل حرم المسجد أو خارجه. 


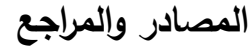

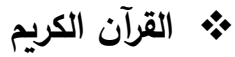

- ابن الأثير ، أبو السعادات المبارك بن محمد الثيباني الجزري. (1979م). النهاية في غريب الحديث والأثر • تحقيق: طاهر أحمد الزاوي - محمود محمد الطناحي. (د. ط). بيروت: المكتبة العلمية. - أحمد، عمر الثيخ إدريس محمد. (2016م). دور الهسجد الدعوي والتربوي - مسجد بحري الكبير ندونجاً (رسالة ماجستير غير منشورة). جامعة الرباط الوطني، المغرب.

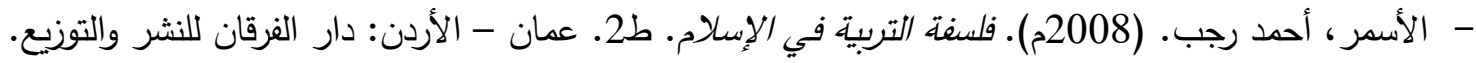
- الأصفهاني، الراغب. (2009م). مغردات ألفاظ القرآن. تحقيق: أبو عبدالله مصطفى بن العدوي. ط1. المنصورة - مصر :

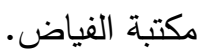
- البخاري، أبو عبدالله محمد بن إسماعيل. (1422هـ). الجامع المسند الصحيح المختصر . تحقيق: محمد زهير بن ناصر الناصر • ط1. (د. م): دار طوق النجاة. - - ابن بطال، أبو الحسن علي بن خلف بن عبد الملك. (2003م). شرح صحيح البخاري. تحقيق: أبو تميم ياسر بن إبراهيم. ط2. الرياض - السعودية: مكتبة الرشد. - الجلاد، ماجد زكي. (2005). تعلم القيم وتعليها - تصور نظري وتطبيقي لطرائق واستراتيجيات تدريس القيم. ط1. عمان الأردن: دار المسيرة. - الجهني، سعود بن بنيان بن عواد الصيدلاني. (1419هـ). الدور التربوي للمسجد النبوي الثريف (رسالة ماجستير غير منشورة). جامعة أم القرى، السعودية. - - ابن حجر العسقلاني، أبو الفضل أحمد بن علي بن حجر الثافعي. (1379هـ). فتح الباري شرح صحيح البخاري. (د. ط). بيروت: دار المعرفة. - خليفة، عبد اللطيف محمد. (1992م). ارتقاء القيم. (د. ط). الكويت: عالم المعرفة.

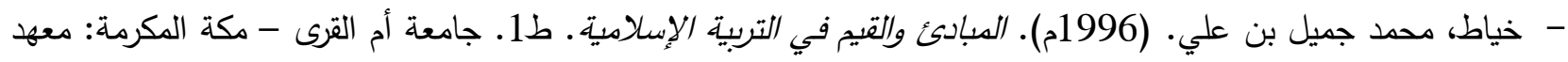
البحوث العلمية وإحياء التراث الإسلامي. - الديب، إبراهيم. (2006م). أسس ومهارات بناء القيم التربوية . ط1. المنصورة - مصر : مؤسسة أم القرى. - - ابن رجب الحنبلي، زين الدين عبد الرحمن بن أحمد بن رجب بن الحسن السلامي البغدادي ثم الدمثقي. (1996م). فتح الباري شرح صحيح البخاري. تحقيق: محمود بن شعبان بن عبد المقصود وآخرون. ط1. القاهرة: مكتب تحقيق دار الحرمين. المدينة النبوية: مكتبة الغرباء الأثرية.

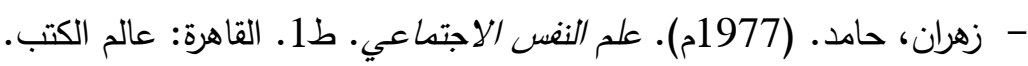
- - سلمان، مشهور حسن. (1996م). القول المبين في أخطاء العصلين. ط4. الدمام - السعودية: دار ابن القيم.

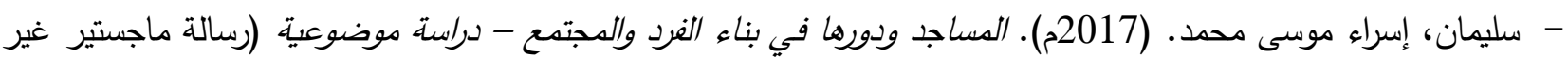
منشورة). الجامعة الإسلامية، غزة.

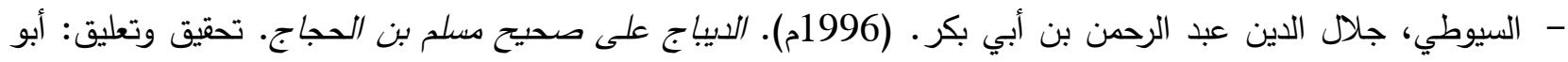
إسحق الحويني الأثري. ط1. الخبر - المملكة العربية السعودية: دار ابن عفان. - الصابوني، محمد علي. (2004م). صفوة التفاسير • ط1. بيروت - لبنان: دار إحياء التراث العربي. 
- عباس، علاء صاحب. (2011م). نحو رؤية فلسفية تربوية للقيم في ضوء القرآن الكريم والسنة النبوية الثريفة. ط1. عمان - الأردن: دار غيداء للنشر والتوزيع. - عبيد، منصور الرفاعي. (1997م). مكانة المسجد ورسالته. ط1. القاهرة: مكتبة الدار العربية للكتاب. - أبو العينين، علي خليل مصطفى. (1988م). القيم الإسلامية والتربية - دراسة في طبيعة القيم ومصادرها ودور الترببية الإسلامية في تكوينها وتنميتها ـ ط1. المدينة المنورة: مكتبة إبراهيم الحلبي.

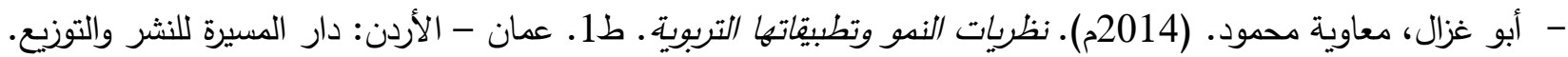
- ابن فارس، أحمد بن زكريا أبو الحسين القزويني الرازي. (2002م). معجم مقاييس اللغة. تحقيق: عبد السلام محمد هارون.

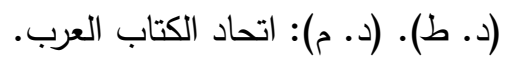
- أبو فارس، محمد عبد القادر • (2009م). دور الهسجد في بناء الأمة والدولة. (د. ط). عمان - الأردن: دار المأمون للنشر

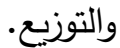
- القاري، علي بن سلطان محمد أبو الحسن نور الدين الملا الهروي. (2002م). مرقاة الدفاتيح شرح مشكاة الدصابيح. ط1.

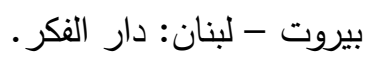
- القسطلاني، أبو العباس شهاب الدين أحمد بن محمد بن أبي بكر بن عبدالملك القتيبي المصري. (1323هـ). إشاد الساري الثرح صحيح البخاري. ط7. مصر : المطبعة الكبرى الأميرية. - القيسي، مروان إبراهيم (1995م). المنظومة القيمية الإسلامية كما تحددت في القرآن الكريم والسنة الثريفة. مجلة دراسات(العلوم الإنسانية)، 22 (6)، 3225. - القيسي، مروان إبراهيم (2004م). سلم القيم الإسلامية من منظور إسلامي. مجلة دراسات (علوم الثريعة والثانون)، 386 ، 31 - ابن قيم الجوزية، شمس الدين محمد بن أبي بكر بن أيوب بن سعد. (1996). مدارج السالكين بين منازل إياك نعبد وإياك

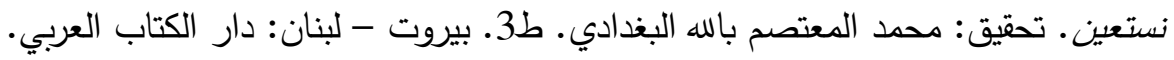

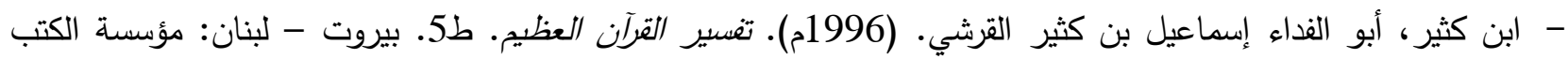

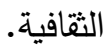
- المانع، مانع بن محمد بن علي. (2005م). القيم بين الإسلام والغرب - دراسة تأصيلية مقارنة . ط1. الرياض - السعودية:

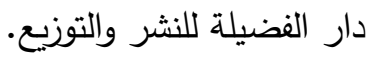
- مسلم، أبو الحسين مسلم بن الحجاج القشيري النيسابوري. (د. ت). المسند الصحيح الدختصر . تحقيق: محمد فؤاد عبد الباقي. (د. ط). بيروت: دار إحياء التراث العربي. - مصطفى، إبراهيم وآخرون. (د. ت). الدعجم الوسيط. (د. ط). استانبول - تركيا: الدكتبة الإسلامية. - معلوف، لويس وآخرون. (2002م). المنجد في اللغنة والأعلام. ط39. بيروت - لبنان: المطبعة الكاثوليكية - دار المشرق.

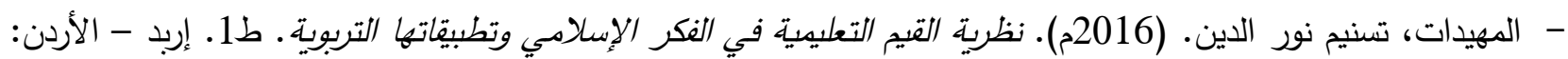

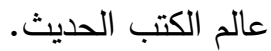
- النووي، أبو زكريا محيي الدين يحيى بن شرف. (1392هـ). الدنهاج شرح صحيح مسلم بن الحجاج. ط2. بيروت: دار إحياء التراث العربي. - اليماني، عبد الكريم علي وآخرون. (2011م). القيم في الفكر التربوي الإسلامي. ط1. عمان - الأردن: دار غيداء للنشر

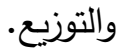




\section{References}

- Ibn Al Atheer, Abu Al- ssaadat Almubarak ibn Muhammed Al- shaibani. (1979). Extremely in unfamiliar Hadith and Tradition (in Arabic).Investigation: Tahir Azzawi- Muhmoud Attunagi, (without Issue). Beirut: Scientific Library. P4/P154.

- Ahmed, Omer Al sheik Idrees, M. (2016). The advocacy and Educational Role of MosqueBahri Grand Mosque as a model (in Arabic).(Unpublished Master Thesis). National Ribat University, Morocco. P57-P66.

- Al- Asmer, Ahmed Rajab. (2008). Education Philosophy in Islam (in Arabic). Second Edition. Amman: Dar Al- Furqan for Publishing.P479.

- Al- Asfahani, Arraghib. (2009). Vocabulary of Quran Words (in Arabic). Investigation: Mustafa ibn Al- Adawi, First Edition. Misr: Al- Fyiad Library.P528

- Al- Bukhari, Abu Abdullah Mohammed bin Ismail. (1422). Sahih Al-Bukhari (in Arabic). Investigation: Mohammed Zuhair bin Nasir. First Edition. (Without Place of Publication): Dar Tawk Annajah.

- Ibn Bttal, Abu- Al Hassan Ali bin Khalaf. (2003). Explanation of Sahih Al- Bukhari (in Arabic). Investigation: Yassir bin Ibrahim, Second Edition. Riyadh- Saudi Arabia: AlRushd Library. P2/P111. P2/P499.

- $\quad$ Al- Jllad, Majid Zaki. (2005). Learning and Teaching Values (in Arabic). First Edition. Amman- Jordan: Dar A1- Masira. P21,P54.

- Al- Juhni, Saud bin Bunyan Al- Suydlani. (1419). The Educational Role of the Prophet's Mosque (in Arabic). (Unpublished Master Thesis). Umm Al- Qura University. Saudi Arabia. P30-P41.

- Ibn Hajr Al- Asqalani, Ahmed Bin Ali. (1379). Opening Creator of Explaining Sahih AlBukhari (in Arabic). (Without Edition). Beruit: Dar Al- Maerifa. P2/P130.

- Khalifa, Abdullatif Mohammed. (1992). Values Elevation (in Arabic). (Without Edition). Kuwait: Ealam Al- Maerifa. P14.

- Khiat, Mohammed Jamil bin Ali. (1996). Principles and Values in Islamic Education (in Arabic). First Edition. Umm Al- Qura- Mekka Almukrrama: Scientific Researchs Institute and Reviving the Islamic Heritage. P47.

- Al- Deeb, I. (2006). Foundations and Skills for Building Educational Values (in Arabic). First Edition. Misr: Umm Al- Qura Foundation. P103.

- Ibn Rajab Al- Hanbali, Abdul Ruhman bin Ahmed Assulami. (1996). Opening Creator of Explaining Sahih Al- Bukhari (in Arabic). Investigation: Muhmoud bin Shaeban and Others. First Edition. Cairo: Dar Al- Haramain Investigation Office. P6/P367. 
- Zahran, H. (1977). Social Psychology (in Arabic). First Edition. Cairo: Ealam Al- Kutub. P132.

- Salman, M. Hasan. (1996). The Clear Saying about the Mistakes of the Worshippers (in Arabic). 4th Edition. Al- Dammam- Saudi Arabia: Dar ibn Al- Qayiem. P205.

- Sulaiman, I. Moses. (2017). Mosques and their Role in Building the Individual and Society (in Arabic). (Unpublished Master Thesis). Islamic University, Gaza. P78-P101.

- Al- Suyuti, Jalaluddin A. (1996). Brocade on Sahih Muslim bin Al- Hajjaj (in Arabic). Investigation: Abu Isaac Al- Huayni. First Edition. Al- kuber- Saudi Arabia: Dar ibn Affan. P3/P110.

- Al- Sabouni, M. Ali. (2004). The Elite of Interpretations (in Arabic). First Edition. Beruit: House of Reviving Arab Heritage. P1/P83.

- Abbass, A. (2011). Towards an Educational Philosophical Vision of Values in the Light of the Holy Qur'an and the Noble Prophet's Sunna (in Arabic). First Edition. Amman: Ghaida Publishing House. P246.

- Obaid, M. Al- Rifai. (1997). The Status and Mission of the Mosque (in Arabic). First Edition. Cairo: Arab House Book Library. P27,P119-137.

- Abu Al- Enein, A. Khalil. (1988). Islamic Values and Education (in Arabic). First Edition. Al- Madina Al- Munawara: Ibrahim A1- Halabi Library. P34,P168. P71-P73.

- Abu Gazal, M. (2014). Growth Theories and their Educational Applications (in Arabic). First Edition. Amman: Al- Masira Publishing House. P153.

- Ibn Faris, A. (2002). ADictionary of Language Standards (in Arabic). Investigation: Abdussalam M. (without Edition). (Without Place to Publish): Arab Writers Union. P48.

- Abu Faris, M. Abdulkader. (2009). The Role of the Mosque in Building the Nation and the State (in Arabic). (Without Edition). Amman: Al- Mamoun Publishing House. P18.

- Al- khari, A. Al- Harawi. (2002). Upgrade Keys Explaining Niche of Lamps (in Arabic). First Edition. Beruit: Dar Al- Fikr. P1/P346.

- Al- Qastalani, Abu Al- Abbass A. Al- Qutaibi. (1323). Guide Walker to Explain Sahih AlBukhari (in Arabic). 7th Edition. Misr: The Great Princely Press. P2/P26.

- Al- Qaisi, M. Ibrahim. (1995). The Islamic Value System as Defined in the Holy Quran and the Noble Sunna (in Arabic). Studies Journal, 22(6), 3225.

- Al- Qaisi, M. Ibrahim. (2004). Ladder of Values from an Islamic Perspective (in Arabic). Studies Journal, 31(2), 386.

- Ibn Qayyim Al- Jawziyyah, M. (1996). Walkers Runways among Status of you we Worship and Call for Help (in Arabic). Investigation: Mohammed Al- Baghdadi. Third Edition. Beruit: Arab Book House. P2/P91.

- Ibn Kathir, I. Al- Qurashi. (1996). Interpretation of the Great Quran (in Arabic). 5th Edition. Beruit: Cultural Books Foundation. P4/P432.

396 IUG Journal of Islamic Studies (Islamic University of Gaza) / CC BY 4.0 
- Al- Manie, M. (2005). Values among Islam and the West (in Arabic). First Edition. Riyad: Dar Al- Fadila Publishing. P24, P272.

- Muslim, Abu Al- Hussien bin Al- Hajjaj Al- Nissabori. (Without Issue). Sahih Muslim (in Arabic). Investigation: Mohammed F. Abdulbaqi. (Without Edition). Beruit: Arab Reviving Heritage House.

- Mustafa, Ibrahim, and Others. (Without Issue). The Intermediate Lexicon (in Arabic). Without Edition. Istanbul- Turkey: Islamic Library.P2/P767.

- Maalouf, Lewis, and Others. (2002). Savior in Language and Flags (in Arabic). 39th Edition. Beruit: The Catholic Press- Dar Almashriq. P321.

- Al- Muhidat, T. Noureddin. (2016). The Theory of Educational Values in Islamic Thought and its Educational Applications (in Arabic). First Edition. Irbed-Jordan: The World of Modern Books. P28.

- Al- Nawawi, Abu Zakaria M. (1392). The Curriculum in Explaining of Sahih Muslim bin Al- Hajjaj (in Arabic). Second Edition. Beruit: Arab Reviving Heritage House. P4/P88.

- Al- Yemani, Abdulkareem A. and Others. (2011). Values in Islamic Educational Thought (in Arabic). First Edition. Amman: Ghaida Publishing House. P122. 